\title{
DOES PCAOB INSPECTION EXPOSURE AFFECT AUDITOR REPORTING DECISIONS?
}

\author{
by \\ Phillip T. Lamoreaux \\ A Dissertation Submitted to the Faculty of the \\ DEPARTMENT OF MANAGEMENT \\ In Partial Fulfillment of the Requirements \\ For the Degree of \\ DOCTOR OF PHILOSOPHY \\ WITH A MAJOR IN ACCOUNTING \\ In the Graduate College \\ THE UNIVERSITY OF ARIZONA
}




\section{THE UNIVERSITY OF ARIZONA GRADUATE COLLEGE}

As members of the Dissertation Committee, we certify that we have read the dissertation prepared by Phillip T. Lamoreaux titled Does PCAOB Inspection Exposure Affect Auditor Reporting Decisions? and recommend that it be accepted as fulfilling the dissertation requirement for the Degree of Doctor of Philosophy.

Date: March 18, 2013

Dan S. Dhaliwal

Date: March 18, 2013

William Felix

Date: March 18, 2013

Lubomir Litov

Date: March 18, 2013

Paul Michas

Final approval and acceptance of this dissertation is contingent upon the candidate's submission of the final copies of the dissertation to the Graduate College.

I hereby certify that I have read this dissertation prepared under my direction and recommend that it be accepted as fulfilling the dissertation requirement.

Date: March 18, 2013

Dissertation Director: Dan S. Dhaliwal 


\section{STATEMENT BY AUTHOR}

This dissertation has been submitted in partial fulfillment of the requirements for an advanced degree at the University of Arizona and is deposited in the University Library to be made available to borrowers under rules of the Library.

Brief quotations from this dissertation are allowable without special permission, provided that an accurate acknowledgement of the source is made. Requests for permission for extended quotation from or reproduction of this manuscript in whole or in part may be granted by head of the major department or the Dean of the Graduate College when in his or her judgment the proposed use of the material is in the interests of scholarship. In all other instances, however, permission must be obtained from the author.

SIGNED: PHILLIP T. LAMOREAUX 


\section{ACKNOWLEDGEMENTS}

I thank my dissertation committee: Dan Dhaliwal (chair), William Felix, Lubomir Litov (finance) and Paul Michas, for their guidance and support. I also would like to thank Dane Christensen, Carol Dee (discussant), Katharine Drake, William Kinney, Stephen Lusch, Landon Mauler, Monica Neamtiu, Nathan Newton, Jayanthi Sunder, Shyam V. Sunder and workshop participants at the University of Arizona, Arizona State University, Brigham Young University Accounting Research Symposium (2012), and AAA audit mid-year meeting (2013) for helpful comments. Previously titled "Blindspots: PCAOB inspection access and auditor reporting conservatism". I thank the Accounting Doctoral Scholars program for funding. 
TABLE OF CONTENTS

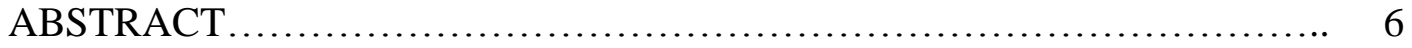

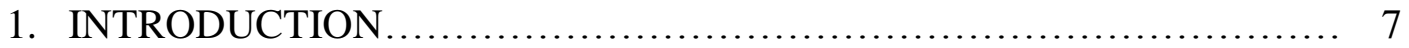

2. PCAOB INSPECTION PROGRAM, PRIOR LITERATURE AND HYPOTHESIS DEVELOPMENT........................................ 14

2.1. PCAOB inspection program.................................. 14

2.2. Prior literature on PCAOB inspections.......................... 15

2.2.1. PCAOB inspections and audit quality................... 16

2.2.2. $\mathrm{PCAOB}$ inspections and perceived audit quality........... 18

2.3. Hypothesis Development...................................... 19

3. RESEARCH DESIGN, SAMPLE, AND DESCRIPTIVE STATISTICS ..... 24

3.1. Research design.......................................... 24

3.1.1. Going concern model............................... 24

3.1.2. Material weakness model............................... 27

3.2. Sample................................................... 29

3.3. Descriptive statistics....................................... 31

4. RESULTS ........................................................ 33

4.1. Impact of inspection exposure on auditor reporting of going concern opinions.................................... 33

4.2. Impact of PCAOB inspection exposure on reporting of material weaknesses............................. 36

5. ADDITIONAL TESTS .............................................. 37

5.1. Actual PCAOB

5.2. Auditor reporting in countries barring inspections ................................................. 38

5.3. U.S. based auditors of foreign companies................................................... 39

6. CONCLUSION .................................................... 40

APPENDIX A: VARIABLE DESCRIPTIONS ............................ 42

APPENDIX B: TABLES.................................................. 45

APPENDIX C: FIGURE ................................................ 56

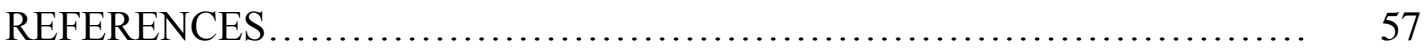




\begin{abstract}
To gain insight into the Public Company Accounting Oversight Board's (PCAOB) impact on audit quality, this study investigates the association between PCAOB inspection exposure (akin to the threat of a PCAOB inspection) and auditor reporting decisions. Certain foreign governments prohibit PCAOB inspections of their domestic auditors of U.S. SEC registrants citing sovereign control. This unique setting provides an opportunity to observe variation in the reach of the PCAOB inspection program and isolate its' effect on auditor reporting. I find that auditors in jurisdictions allowing PCAOB inspections are more likely to report going concern opinions and material weaknesses relative to auditors in jurisdictions barring PCAOB inspections. I find no difference in these auditor reporting propensities in the pre-PCAOB regulatory. This study provides evidence that $\mathrm{PCAOB}$ inspection exposure is associated with auditor reporting incentives, and ultimately audit quality, which is the fundamental purpose of the PCAOB inspection program.
\end{abstract}




\section{INTRODUCTION}

The Sarbanes-Oxley Act of 2002 (SOX) mandates the Public Company Accounting Oversight Board (PCAOB) to inspect all foreign and domestic auditors of U.S. SEC registrants. Since 2005, the PCAOB has collected in excess of $\$ 1.3$ billion in support fees, of which more than $\$ 680$ million has funded the auditor inspection program. Although substantial, this cost excludes the significant time and human capital resources devoted by audit firms to respond to, and participate in, PCAOB inspections. While the PCAOB has lauded the inspection programs' positive impact on audit quality (Hanson 2012), the inspection program has been criticized as fundamentally flawed and the Inspection Reports have been considered to lack "information value" (Glover et al. 2009; Lennox and Pittman 2010). Therefore, the effectiveness of the inspection program, and the cost benefit, remains uncertain. It is important to understand the impact of the inspection program on audit quality given the significant resources devoted to it and the fundamental purpose of the inspection program is to improve audit quality. A rigorous analysis has proven difficult as all auditors of public companies in the US are subject to the inspection program. Further, the inspection program went into effect with other provisions of SOX making it impossible to isolate the impact of the inspection program using time-series comparisons for US auditors.

I use the rich setting of auditors of foreign companies listed in the US. While all auditors of SEC registrants are supposed to be subject to the PCAOB inspection program, certain countries bar the PCAOB from inspecting their domestic auditors citing sovereign 
control. ${ }^{1}$ This setting provides an opportunity to observe variation in the reach of the PCAOB's inspection program, which cannot be done using US data. Therefore, I exploit variation in PCAOB access to conduct inspections of foreign auditors as a proxy for the threat of an auditor inspection and examine the consequences on auditor reporting. This setting is of interest in its own right as the PCAOB has alleged poor audit quality in countries barring inspection access (PCAOB 2011). Therefore, the purpose of this study is to address whether PCAOB inspection exposure influences auditor incentives and ultimately audit quality in a setting that varies the reach of the PCAOB inspection program.

I compare reporting behavior of foreign auditors in jurisdictions allowing PCAOB inspections relative to foreign auditors in jurisdictions barring PCAOB inspections. Involuntary regulator inspection of an auditor's work is analogous to a pre-commitment to disclose audit work papers at the discretion of a regulator. In addition, the PCAOB has enforcement authority over individual auditors and audit firms including authority to levy monetary fines and bar individuals and audit firms from auditing SEC registrants. Furthermore, a bad PCAOB inspection outcome reflects negatively on individual audit partners and employees within their respective firms and therefore provides further incentives to improve audit quality in anticipation of inspection. Therefore, as the probability of inspection of a specific partner or audit client is unknown ex ante, I predict

\footnotetext{
${ }^{1}$ The PCAOB required foreign auditors of US registrants to register with the PCAOB and become subject to PCAOB oversight beginning in July, 2004. Countries that have barred PCAOB inspections citing national sovereignty include: Belgium, China, Cyprus, Denmark, Finland, France, Germany, Greece, Hong Kong, Hungary, Ireland, Italy, Luxembourg, Netherlands, Norway, Portugal, Singapore (until 2008), Spain, Sweden, Switzerland, Turkey, United Kingdom (2008-2010).
} 
inspection exposure (threat of inspection) alone influences auditor incentives, and ultimately audit quality. This reasoning is consistent with DeFond (2010) who suggests mere access to inspect an auditor's work may influence ex ante auditor incentives “in anticipation of the Inspection" (p. 105).

Existing research on the PCAOB inspection program has focused primarily on the observable outcome of an inspection, namely the Inspection Report. This research is also focused in the United States, where auditor exposure to potential PCAOB inspection is unrestricted and unvaried. As PCAOB selection of specific audit engagements to inspect is non-random and "risk-based," a self-selection bias complicates inferences taken from ex post observations of Inspection Reports (Doty 2011). The risk-based approach, while likely appropriate for the purpose of the inspection program, yields empirical results that are akin to "cherry-picking" when inferring audit quality from these reports. Also, the finding in Lennox and Pittman (2010) that audit firms do not experience a significant client portfolio change after publication of a negative inspection report further suggests using inspection reports as an information source about audit quality may be inappropriate. $^{2}$

2 An alternative approach would be to identify those US audit clients most likely to be flagged for inspection by the PCAOB and compare audit quality for these clients to clients least likely to be inspected. Given the PCAOB uses a "risk-based" selection approach (which is unpublished), and the probability of inspection is greater than zero for all clients, designing and drawing appropriate inferences from a test of this nature would be difficult. 
As indicated above, I expect that PCAOB inspection exposure influences auditor incentives, and ultimately auditor behavior in anticipation of an inspection. ${ }^{3}$ In order to test this expectation I use two auditor reporting decisions. I use an auditors' propensity to issue a going concern opinion (Carcello and Neal 2000; 2003; DeFond et al. 2002; Dhaliwal et al. 2012, among others) and an auditors' propensity to report material weaknesses in internal control over financial reporting (Rice and Weber 2012). Examining auditor reporting decisions is particularly useful in this setting as all foreign audits of SEC registrants, regardless of location, must comply with PCAOB auditing standards. Therefore, the benchmark for auditor reporting is consistent across the sample of auditors. If PCAOB inspection exposure influences ex ante auditor incentives, then I expect that, all else constant, auditors subject to PCAOB inspection exposure are more likely to issue going concern opinions and report material weaknesses. However, to the extent that foreign auditors perceive the PCAOB as lacking ability to inflict a cost on them, even with the threat of inspection, I would expect no difference in auditor reporting across jurisdictions regardless of PCAOB inspection exposure.

I find that auditors subject to PCAOB inspection exposure are more likely to issue a going concern opinion after controlling for both economic determinants and country-level institutional characteristics including rule of law. I find no difference in auditor reporting propensities prior to the commencement of the PCAOB inspection program. This finding suggests the difference in an auditor's propensity to issue a going concern opinion is

\footnotetext{
${ }^{3}$ I use PCAOB inspection "access" (the right of the U.S. PCAOB to conduct an auditor inspection in a foreign jurisdiction) and auditor "exposure" to potential PCAOB inspection (auditors residing in jurisdictions that allow U.S. PCAOB inspections) interchangeably throughout the paper.
} 
driven by the PCAOB regulatory period rather than underlying country-level characteristics. These findings are economically meaningful as auditors subject to inspection exposure are more than 50 percent more likely to issue a going concern opinion relative to auditors not subject to inspection exposure, all else constant. Consistent with going concern reporting, I also find that auditors subject to PCAOB inspection exposure are almost twice as likely to report material weaknesses relative to auditors not subject to PCAOB inspection exposure.

To address concerns that the findings above are driven by actual inspections rather than inspection exposure, I hand collect data on the timing of PCAOB inspections of foreign auditors from the published PCAOB Inspection Reports. If auditors properly anticipate the timing of an inspection and modify reporting only when inspection appears imminent, perhaps the impact of inspection exposure identified above is driven solely by the PCAOB's actual inspections rather than exposure alone. I repeat the tests on an auditors' propensity to issue a going concern (material weakness) opinion, controlling for actual PCAOB inspections, and find the results are not driven by actual inspections. I perform a number of additional tests and find that the inferences from the main tests are unchanged, that is, inspection exposure is positively associated with auditor reporting behavior.

This study contributes to our understanding of the impact of the PCAOB's inspection program on auditor reporting incentives and ultimately audit quality in a setting that varies the reach of the PCAOB inspection program, which has not been done previously. Given the cost of the inspection program and its' fundamental purpose is to improve audit 
quality, it is important to understand its' impact on audit quality. This study provides evidence that although the inspection program has flaws, the threat of inspection influences auditor incentives and auditor reporting. This study provides insight on the impact of regulation on auditor incentives and audit quality and thus may be useful to policy makers and regulators.

These results also appear supportive of the recent U.S. SEC decision to require disclosure of whether a company's auditors can be inspected by the PCAOB to inform investors of potential variation in audit quality. Also, by finding that inspection exposure influences auditor reporting, this study is consistent with Srinivasan et al. (2012), a contemporaneous study that examines the restatement behavior of foreign private issuers relative to US registrants that finds the probability of restatement of foreign private issuers is higher in jurisdictions that grant inspection access to the PCAOB. ${ }^{4}$ These results are also consistent with the findings of Carcello et al. (2011a) who find negative market reactions to the PCAOB's public acknowledgement of barred inspection access. Carcello et al. (2011a) suggests investors perceive audit (information) quality is lower in jurisdictions that bar PCAOB inspections. My results are consistent with these investor perceptions.

Lastly, by providing evidence that PCAOB inspection exposure is associated with auditor reporting of material weaknesses, this study also contributes to our understanding

\footnotetext{
${ }^{4}$ The main findings of Srinivasan et al. (2012) examine restatement frequency of foreign private issuers (FPI) and find restatement rates are lower for FPIs relative to US companies. Their examination of $\mathrm{PCAOB}$ inspection exposure is a minor element reported in Table 8 of their paper.
} 
of the relationship between auditor incentives and reported material weaknesses (Rice and Weber 2012).

The remainder of the paper is organized as follows. Section 2 discusses background of the PCAOB inspection program prior literature, and hypothesis development. Section 3 discusses research design, sample selection and descriptive statistics. Section 4 discusses the main results. Section 5 provides additional tests and Section 6 concludes and discusses limitations of the study. 


\section{PCAOB INSPECTION PROGRAM, PRIOR LITERATURE AND HYPOTHESIS DEVELOPMENT}

\subsection{PCAOB inspection program}

The Sarbanes-Oxley Act of 2002 ("SOX") created the PCAOB and mandated it responsibility to regulate all auditors of U.S listed companies. ${ }^{5}$ The primary regulatory mechanism of the PCAOB is its auditor inspection program. The purpose of this program is to assess public accounting firm compliance with the requirements of SOX, the PCAOB, the SEC, and professional standards with the ultimate goal of improving audit quality (SOX, Section 104). A PCAOB inspection of an audit firm is composed of two elements: Part I includes an inspection of audit work papers of non-randomly selected audit client engagements to "identify and address weaknesses and deficiencies related to how a firm conducts audits." Part I of an inspection is of particular interest to my study as this is the primary mechanism to influence ex ante individual auditor reporting incentives. Part II consists of reviewing the quality control and "tone at the top" of the audit firm, including partner compensation arrangements, non-audit service offerings, client acceptance processes, and overall quality control of the audit firm.

Upon completion, an Inspection Report is published detailing the findings of the inspection. If inspectors identify deficiencies in individual audits and the inspectors conclude that the auditors did not have sufficient competent evidence to support the audit opinion, these deficiencies are listed in Part I of an Inspection Report. However, the identity of the audit client remains confidential. The Inspection Report excludes the

\footnotetext{
${ }^{5}$ Prior to SOX the auditing profession was self-regulated through the peer review program of the American Institute of Certified Public Accountants (AICPA). For background information and a comparison of selfregulation of auditors to PCAOB regulation see Kinney (2005) and Hilary and Lennox (2005).
} 
findings of "Part II" of the inspection, unless the audit firm fails to remedy these findings within a 12 month time period. The publication of an Inspection Report is often delayed many months. For example, the Inspection Reports publicizing the results of the inspection of Big 4 fiscal year 2006 audits were published between April and September 2008. Lastly, SOX Section 104 mandates that audit firms who audit more than 100 SEC issuers annually must be inspected annually. Audit firms who audit less than 100 SEC issuers annually are inspected at least once every three years. The PCAOB commenced limited inspections of the US Big 4 audit firms in 2003 with full inspections beginning in 2004. The PCAOB commenced inspections of smaller US audit firms beginning in 2004, and foreign audit firms beginning in 2005 (PCAOB 2004b).

\subsection{Prior literature on $P C A O B$ inspections}

In a commentary, Glover et al. (2009) suggest that while the PCAOB inspection process "has considerable potential for good, in our view the PCAOB's inspection model is not capable of delivering many of the benefits that could be associated with an authoritative inspection process" (p. 231). While the authors support a rigorous inspection program, the flaws identified include, among others, a lack of expertise of and incentives for PCAOB inspectors, lack of experience of inspectors, significant delays in publication of inspections reports, and lack of transparency in the reporting of audit deficiencies. Despite these flaws and the difficulties in drawing appropriate conclusions about audit quality from the Inspection Reports, prior literature has examined the effect of PCAOB inspections on audit quality in primarily two alternative manners. First, 
inferring audit quality from information in PCAOB Inspection Reports. Second, inferring perceived audit quality by observing audit market participant reactions to publication of a PCAOB Inspection Report. The results of these studies are mixed.

\subsubsection{PCAOB inspections and audit quality}

Two recent studies suggest the PCAOB inspection program has made an incremental improvement to audit quality in the United States. Gramling et al. (2011) find some evidence suggesting auditors who have deficiencies identified in their PCAOB Inspection Report increase the likelihood of issuing a going concern opinion after inspection. However, the authors find limited evidence of a change in the likelihood of issuing a going concern opinion for audit firms that had no PCAOB identified deficiencies. In a complementary study, Carcello et al. (2011b) examine the effect of PCAOB inspections on Big 4 audit quality in the United States and conclude that audit quality improved for audits conducted after the first two PCAOB inspections. Given there are more than 2,300 audit firms (foreign and domestic) registered with the PCAOB, the generalizability of this study is limited to the US Big 4 audit firms only. While these studies are informative suggesting audit quality improves after an inspection, they do not capture the full impact of the PCAOB inspection program as they condition on the occurrence of inspection. Furthermore, as auditor exposure to a potential PCAOB inspection is homogeneous across audit firms in the United States, capturing the impact of the PCAOB inspection program on ex ante auditor incentives is difficult in a US setting. 
Rather than test the impact of a PCAOB inspection on audit quality directly, Gunny and Zhang (2009) find that auditors with "seriously deficient" findings in a PCAOB Inspection Report are associated with measures of lower audit quality. The authors do not conclude that the PCAOB inspection program improves audit quality or alters ex ante auditor incentives to improve quality, but rather the PCAOB appropriately infers audit quality in the selection of which audits/audit firms to inspect. This finding is not surprising as the selection of auditors and audit clients for inspection is targeted towards those audits that are more likely to be risky (Doty 2011).

Using a different approach, DeFond and Lennox (2011) address the overall impact of SOX (including PCAOB regulation) on audit quality by examining changes in the market for public company audits. They find a reduction in the number of small auditors auditing public companies in the US and in particular a reduction in the number of small low quality auditors. As a result, the authors infer average audit quality improved, partially attributed to the PCAOB's oversight and inspection program. Their study provides an alternative example of how the potential costs of PCAOB regulation impact auditor incentives and how auditors respond to regulation by the PCAOB. ${ }^{6}$

\footnotetext{
${ }^{6}$ DeFond and Lennox (2011) define low quality auditors as auditors who avoided AICPA peer reviews and failed to comply with PCAOB rules, or received negative peer review and PCAOB Inspection Reports. They find clients of exiting auditors receive higher quality auditing from successor auditors as measured by a greater likelihood of receiving a going concern opinion. Their study does not examine how the PCAOB inspection program influences ex ante auditor incentives to improve audit quality, but rather the mix of auditors offering public company audits. The results also cannot be inferred as driven completely by the PCAOB's inspection program, but driven by all of the regulatory changes resulting from SOX.
} 


\subsection{2. $\quad$ PCAOB inspections and perceived audit quality}

In a study examining audit market responses to information included in a PCAOB Inspection Report, Lennox and Pittman (2010) fail to find net changes in the number of audit clients for audit firms receiving good or bad inspection reports. In contrast, Hilary and Lennox (2005) find audit firms lose clients after negative peer-review reports under the prior AICPA sponsored peer-review regime. Due to the lack of a net change in audit clients after a deficient PCAOB Inspection Report, Lennox and Pittman (2010) ultimately concludes that less is known about audit quality under the PCAOB regulatory era relative to the AIPCA peer review era and thus the PCAOB Inspection Reports lack "information value". While this finding is important, it is tangential to the fundamental purpose of the PCAOB inspection program which is to improve audit quality. As DeFond (2010) indicates, the purpose of the PCAOB inspection program is to assess compliance and therefore does not require the Inspection Reports to be informative as defined in Lennox and Pittman (2010).

Lastly, a recent study, Offermanns and Peek (2011) argues contrary to Lennox and Pittman (2010) and suggests Inspection Reports do provide a meaningful signal of audit quality as measured by increased volatility in stock prices of audit clients around the publication date of their auditor's Inspection Report. They interpret the increased volatility as investors viewing Inspection Reports as a credible source of information about current and future audit quality for audit clients of the inspected audit firm. 


\subsection{Hypothesis Development}

Why would mere exposure to a potential PCAOB inspection influence ex ante auditor incentives to improve audit quality? There are several reasons. First, a PCAOB inspection is outside the control of individual auditors and audit firms and the probability of inspection of a specific client, or specific audit partner is unknown ex ante. While an audit firm may have a high probability of being inspected in a given year, individual audit partners do not know with surety whether their client will be inspected until after the completion of an audit report. Therefore, PCAOB inspection exposure effectively represents a pre-commitment by the individual audit partners to disclose audit work papers to the regulator. Second, the PCAOB is effectively the detective, judge and jury with the ability to both inspect and punish individual auditors and audit firms (Glover et al. 2009). PCAOB Rule 4004 indicates that if an individual auditor or audit firm has violated, or may have violated a rule in SOX, a PCAOB rule, the firms' own quality control practices, or any professional standard, the PCAOB board shall commence an investigation and, if it determines appropriate, report the violation to the SEC and state regulatory authorities (PCAOB 2003a, italics added). Further, the scope of PCAOB enforcement authority is not limited to the audit firm alone. The PCAOB has authority to levy monetary penalties on individual auditors (both partners and employees) and bar them from associating with an accounting firm registered with the PCAOB, thus raising career concerns (PCAOB 2003c). ${ }^{7}$

\footnotetext{
${ }^{7}$ For evidence of PCAOB enforcement activities see http://pcaobus.org/Enforcement/Decisions/Pages/default.aspx.
} 
Third, PCAOB Auditing Standard No. 3 indicates that a final set of audit documentation must be completed no more than 45 days after the report release date (documentation completion date) at which point audit documentation can only be added if the date and reasons for the addition are specifically detailed in the audit file (PCAOB 2004c). Therefore, it is difficult for an auditor to perform substantive additional audit procedures and augment the audit work papers after inspection of an audit engagement becomes certain. Lastly, individual audit partners and employees develop reputational capital within an audit firm for performing high quality audits and a negative PCAOB inspection reflects poorly on this reputation (Houston and Stefaniak 2013). Therefore, the unknown probability of inspection coupled with costs to individual auditors would likely influence ex ante auditor incentives to improve audit quality if they are subject to PCAOB inspection exposure. ${ }^{8}$ This conjecture is consistent with DeFond $(2010,105)$ which states "If the PCAOB Inspectors hold auditors to stricter standards [stricter than previous peer-reviewers] and are able to impose costly penalties, auditors will have incentives to improve audit quality in anticipation of Inspections."

While there are reasons to believe PCAOB inspection exposure influences ex ante auditor incentives to improve audit quality, there are also reasons to believe PCAOB inspection exposure may not improve audit quality, particularly in foreign auditors outside the United States. First, foreign auditors, while subject to PCAOB rules and inspection, may believe the PCAOB lacks ability to enforce regulations outside of the

\footnotetext{
${ }^{8}$ The enforcement ability of the PCAOB is a significant change from the peer-review program under the AICPA. While the PCAOB has published a small number of settled enforcement actions on its website, it has indicated the majority of enforcement activity goes unnoticed by the public.
} 
US. ${ }^{9}$ Second, the PCAOB may not conduct planned inspections on time and as such auditors may believe the probability of inspection is remote. ${ }^{10}$ Third, Rule 4012 permits the PCAOB Board to rely, to a degree deemed appropriate, on inspections conducted by oversight regulators in foreign jurisdictions. The degree of PCAOB reliance increases with independence and rigor of local oversight inferring that quality inspections by local regulators may substitute for, to a degree, an inspection by the PCAOB. ${ }^{11}$

If exposure to a potential PCAOB inspection influences ex ante auditor incentives, then I would expect a positive association between PCAOB exposure and audit quality. As all audits of SEC registrants, regardless of location, must comply with PCAOB auditing standards, I measure audit quality using auditor reporting decisions, specifically, the propensity of an auditor to issue a going concern opinion (Carey and Simnett 2006; DeFond et al. 2002; Dhaliwal et al. 2012, among others) and the propensity of an auditor to report a material weakness in internal control over financial reporting (Rice and Weber 2012). Prior research suggests that auditor incentives (particularly an auditor's cost function) influence the probability of issuing a going concern opinion (e.g. Kida 1980, Reynolds and Francis 2000). I consider a higher probability of a going concern opinion to be higher audit quality as audit clients face negative outcomes (e.g. "self-fulfilling prophecy") and auditors face potential costs as a result of issuing a going concern opinion

\footnotetext{
9 The PCAOB has settled enforcement actions in only two countries (Australia, India) outside the United States.

${ }^{10}$ For example, PCAOB Release 2008-04 delayed the deadline for certain foreign registered accounting firms to be inspected from 2008 to 2009.

11 The PCAOB had the option to rely completely on foreign audit regulators to inspect foreign auditors of companies listed in the US. The PCAOB chose not to rely completely on foreign inspections citing concerns about audit quality. Ultimately, the PCAOB has moved toward cooperative inspections with the PCAOB and local regulators assisting in one another's regulatory compliance programs. See www.pcaobus.org/International for more information regarding the cooperative agreements.
} 
regardless of the going concern opinions predictive ability of subsequent bankruptcy (e.g. Carcello and Neal 2000). ${ }^{12}$

If PCAOB inspection exposure influences auditor incentives to improve audit quality, or auditors believe poor audit quality discovered in a PCAOB inspection will inflict costs to the audit firm or partner (e.g. reputation loss, client loss, etc.) then I expect that auditor exposure to a potential PCAOB inspection is positively associated with an auditor's propensity to issue a going concern opinion. I test the following hypothesis stated in the alternative form:

Hla: PCAOB inspection exposure is positively associated with an auditor's propensity to issue a going concern opinion.

Consistent with $\mathrm{H} 1 \mathrm{a}$, if $\mathrm{PCAOB}$ inspection exposure influences auditor reporting incentives, then I expect that commencement of PCAOB inspection access increases the probability of a going concern opinion relative to the pre-PCAOB access period.

H1b: Ceteris paribus, Auditors subject to PCAOB inspection exposure are more

likely to issue a going concern opinion post-PCOAB inspection access relative to the pre-PCAOB inspection period.

12 Given there are differences in financial reporting and enforcement of accounting standards across countries (Holthausen 2009; Leuz et al. 2003), I use the going concern (material weakness) opinion as a proxy for audit quality rather than other commonly used proxies for earnings management such as abnormal accruals and the propensity to meet or beat analyst earnings forecasts as these other earnings management measures are a joint function of the client and the auditor whereas the audit opinion is a decision made by the auditor upon completion of an audit. 
Beginning in 2006, foreign private issuers are required to report on the effectiveness of their internal controls over financial reporting (ICFR), and an auditor must attest to their report in accordance with SOX Section $404 .{ }^{13}$ Because SOX 404 requires an auditor to opine on the effectiveness of a client's ICFR, and this opinion is subject to PCAOB inspection, I also measure audit quality with the propensity of an auditor to identify and report a material weakness in ICFR. Furthermore, reviews of recent PCAOB Inspection Reports find that the PCAOB identifies and reports deficiencies in internal controls over financial reporting which further reinforces the usefulness of examining auditor reporting of internal control quality. I interpret a higher propensity of an auditor to report a material weakness as higher audit quality because clients likely ex ante prefer a "clean" opinion on their ICFR given the costs associated with reported material weaknesses (e.g. Ashbaugh-Skaife et al. 2009). The hypothesis for my second proxy for audit quality is stated in the alternative form as follows:

H2: PCAOB inspection exposure is positively associated with an auditor's propensity to report a material weakness in internal control over financial reporting.

\footnotetext{
${ }^{13}$ Foreign private issuers (FPIs) that are "larger accelerated filers" must comply with SOX Section 404 beginning with fiscal year 2006. FPIs that are "accelerated filers" must comply with SOX 404 beginning in 2007. Voluntary compliance was permitted prior to these dates.
} 


\section{RESEARCH DESIGN, SAMPLE, AND DESCRIPTIVE STATISTICS}

\subsection{Research design}

\subsubsection{Going concern model}

In the first audit quality test, I examine the association between PCAOB inspection exposure (ACCESS) and the propensity of an auditor to issue a going concern opinion with the following model (company and year subscripts omitted):

$$
\begin{aligned}
\operatorname{Pr}\left(G O I N G \_C\right. & O N C E R N=1)=\beta_{0}+\beta_{1} A C C E S S+\beta_{2} S I Z E+\beta_{3} L O S S+\beta_{4} R O A \\
& +\beta_{5} \text { altZSCORE }+\beta_{6} C A S H+\beta_{7} L E V+\beta_{8} R E P L A G+\beta_{9} A G E+\beta_{10} M T B \\
& +\beta_{11} O P C F+\beta_{12} L A G_{-} G C+\beta_{13} C R O S S+\beta_{14} M A J O R+\beta_{15} B 4+\beta_{16} I F R S \\
& +\beta_{17} H I G H L I T+\beta_{18} R U L E \_O F \_L A W+\beta_{19} G D P \_C A P I T A \\
& +\beta_{20} G D P \_G R O W T H+\beta_{21} L \_G D P+\beta_{21} M K T \_S I Z E \\
& +\beta_{22} D I F F \_L A W+\beta_{23} L I A B I L I T Y+y e a r F E+e
\end{aligned}
$$

The dependent variable (GOING_CONCERN) is equal to one if the company-year receives a going concern opinion, zero otherwise. ACCESS is an indicator variable equal to one if the U.S. PCAOB has access to conduct inspections in the foreign jurisdiction, thus subjecting auditors to a potential PCAOB inspection, ACCESS is equal to zero if inspection access has been barred. The control variables are based primarily on prior research. I control for a company's ability to meet ongoing financial obligations and common economic determinants of a going concern opinion including total assets as a proxy for company size (SIZE), an indicator variable equal to one if the company reports a loss (LOSS), return on assets (ROA), Altman (1968) probability of bankruptcy score (altZSCORE), cash holdings scaled by total assets $(C A S H)$, leverage ratio $(L E V)$, number 
of days after year-end that the audit report is published (REPLAG), natural log of number of years included in the COMPUSTAT database as a proxy for company age $(A G E)$, market to book ratio $(M T B)$, and operating cash flows of the company scaled by total assets (OPCF) (Carcello and Neal 2000; DeFond et al. 2002; Gramling et al. 2011). As an auditor faces greater pressures to not report going concern opinions when a client received a "clean" opinion in the prior year, I include a dummy variable $\left(L A G \_G C\right)$ equal to one if the previous year's audit report included a going concern explanatory paragraph (Carcello and Neal 2000; Reynolds and Francis 2000). ${ }^{14}$

While my sample only includes foreign companies listed in the United States, I control for the impact of complementary governance mechanisms from stock exchange listings elsewhere in the world. I include a dummy variable (CROSS) equal to one if the company is listed on a foreign stock exchange. I also control for listing on a major foreign stock exchange because governance mechanisms for these major exchanges may further impact auditor reporting incentives due to increased exposure for the audit firm. MAJOR is a dummy variable equal to one if the company is listed on a major stock exchange outside the United States defined as stock listings on the Borse Frankfurt, Hong Kong, London or Tokyo stock exchanges (www.guides.lib.uchicago.edu). I also control for variation in auditor reporting with a dummy variable (B4) equal to one if a company is audited by an affiliate of the Big four audit firms.

\footnotetext{
${ }^{14}$ Some prior studies have examined "first-time" going concern opinions (e. g. Carcello and Neal 2003). In untabulated results I examine only going concern opinions in which a clean opinion was issued in the prior year and find my results are qualitatively unchanged.
} 
Foreign companies listed in the United States can report their financial statements based on US GAAP, domestic GAAP with reconciliation to US GAAP or IFRS as issued by the IASB. ${ }^{15}$ To control for the potential effect of accounting standards on auditor reporting behavior I identify those company-years that report on IFRS as issued by the IASB and create an indicator variable (IFRS) equal to one for such company-years. HIGHLIT is an indicator variable equal to one if a company operates in a highly litigious industry as certain industries in the US are more prone to litigation (Rogers and Stocken 2005 see Appendix for definition).

To control for a country-level impact on auditor reporting decisions I include a variety of country-level control variables which have been used in prior research. I control for rule of law (RULE_OF_LAW) in the auditors' country to capture the extent to which auditor reporting varies by rule of law. $R U L E \_O F_{-} L A W$ is taken from the World Bank Indices (Kaufmann et al. 2010, p. 4) and it measures "the extent to which agents have confidence in and abide by the rules of society, and in particular the quality of contract enforcement, the police, and the courts, as well as the likelihood of crime and violence.” I use $R U L E \_O F \_L A W$ rather than other common measures (i.e. measurement identified in La Porta et al. 1999) as the Kaufmann et al. (2010) measure has wider coverage across countries to maximize sample size and varies within countries across time. I measure $R U L E \_O F_{\_} L A W$ on a scale of 0.0 to 1.0 with 1.0 representing a higher overall level of rule of law. As audit liability regimes vary throughout the world, I

\footnotetext{
15 A reconciliation to US GAAP from IFRS as issued by the IASB is not required beginning with fiscal years ending after November 15, 2007 (SEC 2007).
} 
include LIABILITY which is a measure of accountant liability defined in La Porta et al. (2006) that measures the procedural difficulty in recovering losses from an auditor in a civil liability case at the country-level. I also include the natural log of a countries' Gross Domestic Product $\left(L_{-} G D P\right)$, Gross Domestic Product per capita (GDP_CAPITA) and change in Gross Domestic Product (GDP_GROWTH) to control for country size, wealth, economic growth and other factors that may influence auditor reporting and effort at the country level. MKT_SIZE is the country's total market capitalization scaled by GDP for each year (Michas 2011).

Lastly, I include DIFF_LAW which is the difference between the Kaufmann et al. (2010) measure of rule of law at the auditor jurisdiction and the company-headquarter jurisdiction level. Companies in low rule of law countries may attempt to obtain higher audit quality by contracting with audit firms from higher rule of law countries. I include year fixed effects in all models and cluster standard errors at the company-level. ${ }^{16} 17$

\subsubsection{Material weakness model}

For the second audit quality test (H2), I examine the association between PCAOB inspection access $(A C C E S S)$ and auditor reported material weaknesses in internal control over financial reporting $(M W)$. I use the following model based on Doyle et al. (2007) (company and year subscripts omitted):

${ }^{16}$ In untabulated results I also include industry fixed effects in all regressions and find the results are qualitatively unchanged.

${ }^{17}$ Consistent with Michas (2011) I do not include country-level fixed effects as my variable of interest (ACCESS) does not vary across time. Consequently, I control for various country-level characteristics to capture country-level institutional effects on audit quality and address concerns identified in Gordon et al. (2012). 


$$
\begin{aligned}
\operatorname{Pr}(M W & =1)=\beta_{0}+\beta_{1} \text { ACCESS }+\beta_{2} \text { SIZE }+\beta_{3} L O S S+\beta_{4} \text { altZSCORE } \\
& +\beta_{5} L \_S E G M E N T S+\beta_{6} A G E+\beta_{7} S \_G R O W T H+\beta_{8} D \_R E S T R U C T U R E \\
& +\beta_{9} D \_A C Q U I S I T I O N+\beta_{10} C R O S S+\beta_{11} M A J O R+\beta_{12} B 4+\beta_{13} I F R S \\
& +\beta_{14} \text { HIGHLIT }+\beta_{15} R U L E \_O F \_L A W+\beta_{16} G D P \_C A P I T A \\
& +\beta_{17} \text { GDP_GROWTH }+\beta_{18} L \text { GDP }+\beta_{19} \text { MKT_SIZE } \\
& +\beta_{20} \text { DIFF_LAW }+\beta_{21} \text { LIABILITY }+ \text { year FE }+e
\end{aligned}
$$

The dependent variable $(M W)$ is equal to one if the audit opinion on internal control over financial reporting identifies at least one material weakness, zero otherwise. The variable of interest, ACCESS, is as previously defined. I include control variables previously associated with the reporting of material weaknesses including company size, which I measure as total assets (SIZE), an indicator variable equal to one if the company reports a loss in the current year (LOSS) as companies with stronger financial health have more resources to devote to internal control quality and the Altman (1968) bankruptcy risk score (altZSCORE) to further address financial health of the company. I include $A G E$ (as previously defined) as younger companies are more likely to face control weaknesses relative to older companies with established accounting and control procedures. To capture complexity of operations I include L_SEGMENTS which is the natural $\log$ of business and operating segments. To control for internal control deficiencies associated with rapid growth I include year-over-year sales growth $\left(S \_G R O W T H\right)$. I also include dummy variables to capture restructuring (D_RESTRUCTURE) and acquisition activity (D_ACQUISITION). Consistent with the 
going concern model I control for factors that may influence auditor reporting incentives including foreign stock listing (CROSS, MAJOR), Big 4 auditor (B4), accounting standards (IFRS), rule of law (RULE_OF_LAW, DIFF_LAW), and country-level institutional variables $\quad\left(G D P \_C A P I T A, \quad G D P \_G R O W T H, \quad L \_G D P, \quad M K T \_S I Z E\right.$, LIABILITY) as previously defined.

\subsection{Sample}

My analysis is conducted at the company-year level and the primary analysis includes all company-years of foreign companies listed in the United States during the period 2004-2010. I classify companies as foreign if they are headquartered outside the United States. I include both American Depository Receipts (ADRs) and foreign companies directly listed in the US. I begin with 2004 year-end reports as all foreign auditors of US listed companies or foreign auditors who play a "substantial role" in the preparation of US audit reports are required to register with the PCAOB no later than July 19, $2004 .^{18}$ Once an audit firm registers with the PCAOB it becomes subject to PCAOB auditor inspections and enforcement (PCAOB 2003b, 2004a). I then exclude company-years missing necessary control variables, financial companies (SIC code 6000-6999), company-years with less than $\$ 1$ million in total assets, and company-years audited by U.S. auditors.

\footnotetext{
18 "Substantial role" is defined in PCAOB Rule 1001 (p)(ii) as an audit firm performing material services that are relied on to issue an audit report, or performing the majority of audit procedures for a subsidiary that comprises 20 percent or more of consolidated assets or revenues of an SEC Issuer.
} 
Table 1 Panel A outlines the sample selection criteria and Table 1 Panel B outlines the company-years and the number of unique auditors by year. The main sample consists of 4,670 company-years which represents 1,089 unique companies and 231 unique auditors. To conduct tests of $\mathrm{H} 1 \mathrm{~b}$, I add company-years meeting the above data requirements for the period 2001-2003 and obtain a sample of 6,233 company-years for this test. To test $\mathrm{H} 2$, auditor reporting of material weaknesses, I limit the main sample to those company-years with SOX 404 audit opinion data as identified in the Audit Analytics database. The sample for the material weakness reporting test consists of 1,905 company-years and 140 unique auditors.

As I examine the impact of PCAOB inspection exposure on auditor reporting incentives I identify those jurisdictions that bar the PCAOB inspection access by hand collecting data from the PCAOB website (www.pcaobus.org). I find that with the exception of Singapore and the United Kingdom, no country changed PCAOB inspection access privileges during the sample period. ${ }^{19}$ As indicated previously, I define my variable of interest (ACCESS) equal to one for all company-years in which the PCAOB has access to inspect audits. ${ }^{20}$ For tests of H1b, (company-years 2001-2003), I code

\footnotetext{
${ }^{19}$ Singapore initially barred PCAOB inspection of local auditors, and then in 2008 signed a cooperative inspection agreement with the PCAOB. The United Kingdom permitted PCAOB inspection until 2008 when the U.K. Professional Oversight Board (POB) barred PCAOB inspection access. Lastly, for auditors residing in Hong Kong, the PCAOB is barred inspection access for audits of companies headquartered in mainland China.

${ }^{20}$ The PCAOB is attempting to inspect all auditors of SEC registrants including those in countries barring inspection access. As evidence, the PCAOB recently signed a Statement of Protocol with the Auditor Oversight Commission of Germany (AOC) on April 4, 2012, a jurisdiction which has historically barred PCAOB inspection access. The Statement of Protocol outlines an approach to conduct joint inspections by the PCAOB and the AOC. The outcome of this Statement of Protocol does not impact the results or inferences from my tests as I conduct tests on fiscal years up through 2010.
} 
ACCESS equal to one if the jurisdiction grants the U.S. PCAOB inspection access upon commencement of PCAOB regulation (i.e. fiscal year 2004).

\subsection{Descriptive statistics}

Table 2 partitions the samples on auditor inspection exposure $(A C C E S S=1$, or 0$)$, for the dependent variables GOING_CONCERN and $M W$. There are a total of 3,496 company-years the PCAOB has access to inspect (ACCESS equals one) and 1,174 company-years the PCAOB cannot inspect (ACCESS equals zero) for the going concern sample. Of the 3,496 company-years subject to potential PCAOB inspection (N), 10.2 percent received a going concern opinion (GC) while 2.6 percent of non-PCAOB access company-years received a going concern opinion. There are 1,693 company-years in the "distressed" going concern sample (N-distressed) which I define as company-years reporting a loss or negative cash flows from operations, a situation in which a going concern opinion is more salient. Of the company-years subject to potential PCAOB inspection in the distressed sample, 20.0 percent received a going concern opinion (GCdistressed) while 8.2 percent of the non-PCAOB access company-years received a going concern opinion.

In the material weakness sample there are 1,427 company-years subject to potential PCAOB inspection and 629 company-years for which PCAOB inspection is barred (NMW). Of the company-years subject to potential inspection, 8.1 percent received a material weakness (MW), while 6.8 percent of the non-PCAOB access company-years

received a material weakness. Although the above comparisons seem to support the 
hypothesis that PCAOB inspection access is associated with auditor reporting, I do not draw conclusions given the samples of company-years are not homogeneous across access and non-access granting countries.

Table 3 provides descriptive statistics of the dependent and independent variables partitioned on PCAOB inspection access. Company-years whose auditors are barred from inspection access are larger (SIZE), more profitable (ROA, LOSS), and are more likely to use a Big 4 auditor (B4) relative to company-years whose auditors are permitted to be inspected by the PCAOB.

Table 4 presents correlations among my variable of interest (ACCESS) and country-level control variables. Table 4 Panel A presents the correlations for the going concern sample $(n=4,670)$, Panel B presents correlations for the distressed going concern sample $(n=2,025)$ and Panel C presents correlations for the material weakness sample $(n=1,905)$. For the going concern sample (Panel A) ACCESS is positively significantly correlated with RULE_OF_LAW (0.12), GDP_GROWTH (0.05), GDP_CAPITA (0.04) and LIABILITY (0.38) and negatively significantly correlated with MKT_SIZE (-0.23). Correlations in Panel B and Panel C are qualitatively consistent with those reported in Panel A. To address concerns about multicollinearity in my regression analysis, I calculate VIF values and find they are all less than 10. Therefore, there are no issues with collinearity (Kennedy 2008). 


\section{RESULTS}

\subsection{Impact of inspection exposure on auditor reporting of going concern opinions}

Table 5 reports the results of Equation (1). Column (1) reports the results on the sample of foreign companies for the period 2004-2010. The coefficient on ACCESS is positive and statistically significant $(p$-value $<0.01)$ suggesting that auditors subject to a threat of PCAOB inspection are more likely to issue a going concern opinion. The coefficient on ACCESS is economically meaningful as ACCESS increases the probability of a going concern opinion from from 5.6 to 8.9 percent. As a going concern opinion is more salient for financially distressed firms, Column (2) restricts the sample to companyyears reporting either a loss or negative cash flows from operations. Again, I find that the coefficient on ACCESS is positive and statistically significant ( $p$-value 0.07). The coefficient on ACCESS in this distressed setting is also economically meaningful as ACCESS increase the probability of a going concern opinion from 13.7 to 18.7 percent. The coefficients on common economic determinants of a going concern opinion are largely consistent with prior research. Larger (SIZE), more profitable $(R O A)$, higher cash balance $(C A S H)$ companies are less likely to receive a going concern opinion, while companies with a previous going concern opinion $\left(L A G \_G C\right)$, a reported loss $(L O S S)$, higher leverage $(L E V)$, and longer audit report lag $\left(R E P_{-} L A G\right)$, are more likely to receive a going concern opinion. With respect to country-level control variables I find that $G D P \_C A P I T A$ and $L \_G D P$ are positively associated with $G O I N G \_C O N C E R N .^{21}$

${ }^{21}$ Goh et al. (2012) find that a reported material weakness under SOX 404 increases the likelihood of an auditor issuing a going concern opinion. In untabulated results using the material weakness sample $(\mathrm{n}=1,905)$, I find my result on $A C C E S S$ is unchanged after controlling for material weaknesses $(M W)$ in 
Table 6 reports the results of testing H1b. Table 6, Column (1) reports the results of Equation (1) on the pre-PCAOB observations only, that, is all company-years prior to 2004. I find that the coefficient on ACCESS is statistically insignificant suggesting there is no difference in the propensity to report a going concern opinion across auditors in access granting, and non-access granting jurisdictions prior to the commencement of PCAOB inspections. Table 6 Column (2) reports the results for all observations from 2001 through 2010 (pre- and post-PCAOB inspection access, $(n=6,232)$. Table 6 Column (3) reports results for distressed company-years 2001-2010 (n=2,792). I then include an indicator variable (POST) equal to one in Equation (1) to indicate in which audits are subject to a threat of a potential PCAOB inspection. POST is equal to one for all audits beginning with fiscal year 2004 financial statements as foreign auditors were required to register with the PCAOB in 2004. I then interact POST with ACCESS to identify the impact of inspection exposure in the PCAOB regulatory period, controlling auditor reporting in the pre-inspection period (ACCESS). To test $\mathrm{H} 1 \mathrm{~b}$, I expect that PCAOB inspection access influences auditor reporting only during the PCAOB regulatory period where (POST*ACCESS=1). Consistent with this expectation I find positive and significant coefficients on POST*ACCESS ( $p$-value <0.01) in the pooled and distressed samples (Columns (2) and (3)) and a statistically insignificant coefficient on ACCESS in the pooled sample and a negative and weakly statistically significant coefficient on ACCESS $(p$-value $=0.08)$ in the distressed sample.

Equation 1. Also in untabulated results I drop all non-B4 observations and find that ACCESS is positively associated with GOING_CONCERN in the subsample of Big 4 affiliate auditors. 
With respect to the interaction term $\left(P O S T^{*} A C C E S S\right)$ reported in Table 6, Ai and Norton (2003) and Norton, Wang and Ai (2004) show that for nonlinear models such as a logistic model, the total interaction effect can have a different sign and statistical significance from the sign and statistical significance observed in a $t$-test on the estimated interaction term. $\mathrm{Ai}$ and Norton (2003) suggest including graphical evidence to supplement the logistic model results to address statistical and economic significance of the interaction term. Figure 1 plots $\mathrm{z}$-statistics for the total interaction effect of POST*ACCESS for models reported in Columns (2) and (3) of Table 6. The x-axis plots the predicted probability of GOING_CONCERN equal to one, while the y-axis plots the z-statistic (statistical significance) of the interaction term POST*ACCESS. The results are quite intuitive. When the predicted probability of GOING_CONCERN is close to zero (i.e. profitable, high cash flow companies), or close to one (i.e. imminent bankruptcy and extremely poor performance) the coefficient on the interaction term (POST*ACCESS) is statistically insignificant. However, when the predicted probability that GOING_CONCERN equals one ranges between approx 0.15 and 0.90 , the interaction term is positive and highly statistically significant. Thus, this graphical evidence suggests that PCAOB inspection exposure is positively associated with auditor reporting decisions only in those situations requiring auditor judgment, supporting the notion that inspection exposure influences auditor incentives, in particular in settings requiring auditor judgment. 
4.2. Impact of PCAOB inspection exposure on auditor reporting of material weaknesses. Table 7 reports the results of Equation (2) analyzing the association between PCAOB inspection exposure and the propensity of an auditor to report a material weakness in a company's internal controls over financial reporting. The coefficient on ACCESS is positive and statistically significant ( $p$-value 0.03 ) suggesting that auditors subject to inspection exposure are more likely to report material weaknesses. The coefficient on ACCESS is economically meaningful as ACCESS increases the probability of an auditor reported material weakness from 4.5 percent to 8.7 percent. With respect to the control variables, companies that are cross-listed (CROSS), audited by a Big 4 audit firm (B4), or older (AGE), are less likely to have reported material weaknesses, while, companies reporting a loss $(L O S S)$ or audited by an auditor from a higher rule of law regime $\left(D I F F_{-} L A W\right)$ are more likely to have reported material weaknesses. 


\section{ADDITIONAL TESTS}

I perform a number of additional tests as a validity check on the main results reported above which suggest PCAOB inspection exposure is associated with auditor reporting decisions. The tests are as follows:

\subsection{Actual PCAOB Inspections}

To address concerns that the results reported in Tables 5 and 7 are driven by actual PCAOB inspections rather than inspection exposure alone, I hand-collect data from all PCAOB Inspection Reports of auditors in my sample of company-years listed in Table 1. While the PCAOB does not publish which audit client work papers are inspected by the PCAOB, one can infer which fiscal-year end audits were inspected based upon the timing of PCAOB inspection fieldwork which is disclosed in the Inspection Reports. Therefore, to the extent auditors "game the system" and predict and modify behavior only when inspections are most likely to occur, perhaps the result on inspection exposure (ACCESS) is driven by auditor reporting on fiscal-year ends that were ultimately inspected by the PCAOB rather than those simply subject to inspection exposure. I create a variable (INSPECTED_FYEAR) equal to one for all fiscal-year-end audit reports that were inspected by the PCAOB. For example, each PCAOB Inspection Report identifies the dates that inspection field work occurred, (e.g. July 17- July 24). I then code INSPECTED_FYEAR equal to one for company-year observations (audited by the audit firm that was inspected) with fiscal years ending in the year prior to the inspection field work dates for all inspection field work dates after April 30. If PCAOB inspection field work is performed between January and April, I code INSPECTED_FYEAR equal to one 
for company-year observations with fiscal years ending two years prior to the inspection field work year.

Table 8 Column (1) reports the results of Equation (1) controlling for actual PCAOB inspections. The coefficient on ACCESS remains positive and statistically significant ( $p$ value $<0.01)$ while the coefficient on INSPECTED_FYEAR is not statistically different than zero suggesting inspection exposure (the unknown probability of inspection) influences going concern reporting even after controlling for actual PCAOB inspections. I find a similar result (untabulated) in the reduced sample of "distressed" company-years. Table 9 Column (1) reports the results including INSPECTED_FYEAR in Equation (2) examining an auditor's propensity to report material weaknesses. The coefficient on ACCESS is positive and statistically significant (p-value 0.03 ) while the coefficient on INSPECTED_FYEAR is statistically insignificant suggesting actual inspection does not drive the results reported in Table 7.

\subsection{Auditor reporting in countries barring inspections}

To address whether countries that grant and do not grant inspection access are inherently different, I reduce the sample to include only observations of companies headquartered in countries that bar inspection access $(n=1,029)$. The variables ACCESS now measures the effect of auditors residing in a country that permits PCAOB inspection, but auditing a client located in a jurisdiction barring PCAOB inspection (e.g. a Canadianbased auditor auditing a 2005 year-end Chinese company's financial statements). As PCAOB inspection exposure is driven by the auditor location rather than client location, I 
examine the association between ACCESS and auditor reporting decisions for this subsample. Table 8, Column (2) reports the results for the going concern sample, while Table 9, Column (2) reports the results for the material weakness sample. Again, I find that the coefficient on ACCESS is positive and statistically significantly associated with the propensity to issue a going concern $(p$-value $<0.01)$ and material weakness opinion ( $p$-value 0.06) again suggesting that PCAOB inspection exposure influences auditor reporting outcomes.

\subsection{U.S. based auditors of foreign companies}

Lastly, Table 1 indicates there are 815 observations of foreign companies listed in the U.S. that are audited by U.S. based audit firms (i.e. the auditor opining on the financial statements resides in the U.S.). ${ }^{22}$ As inspection exposure is driven by auditor location and not client location, if inspection exposure influences auditor reporting there should be no difference in the propensity of U.S. based auditors to issue going concern (material weakness) opinions across clients in PCAOB access and non-access granting jurisdictions. Consistent with this expectation, I find (untabulated) no difference in the propensity of U.S. auditors to report a going concern or material weakness opinion across clients that are based in access and non-access granting jurisdictions.

\footnotetext{
${ }^{22}$ The PCAOB has made reference to this practice and expressed concerns regarding who is actually conducting the audit work and whether the U.S. based auditor qualifies as the principal auditor under PCAOB auditing standards (PCAOB 2010).
} 


\section{CONCLUSION}

The PCAOB has been charged with overseeing all auditors of US listed companies, with its inspection program as the primary regulatory mechanism. The fundamental purpose of the PCAOB's inspection program is to improve audit quality yet it is difficult to empirically examine the inspection programs impact. The governments of certain countries have barred the U.S. PCAOB access to conduct auditor inspections and this setting provides an opportunity to observe variation in the reach of the inspection program and thus its impact on audit quality. I find that even though the inspection program has flaws, the threat of a PCAOB inspection is positively associated with auditor reporting of both going concern and material weakness opinions. These results suggest the mere threat of disclosing audit work papers through inspection coupled with potential enforcement incentivize auditor's to improve quality. This paper contributes to the literature by providing evidence that inspection exposure is positively associated with audit quality.

There are several limitations to consider with this study. First, inspection exposure may be correlated with some country-level characteristic which drives both the jurisdictions decision to grant inspection access and the reporting behavior of auditors for which I have not sufficiently controlled. Second, inspection exposure may instill overly conservative auditor reporting behavior rather than improve audit quality and the above results may reflect overly conservative reporting rather than higher audit quality. Lastly, even though I find inspection exposure is associated with auditor reporting decisions, this study does not weigh all of the costs and benefits of the PCAOB inspection program and 
therefore I do not conclude whether PCAOB inspection and enforcement is an optimal form of auditor regulation as it is currently carried out (i.e. Pagano and Immordino 2007). It is still possible that the costs (in excess of $\$ 680$ million since 2005) or flaws in the inspection program outweigh the benefits. 


\section{APPENDIX A: VARIABLE DESCRIPTIONS}

\begin{tabular}{|c|c|}
\hline Variable & Description \\
\hline \multicolumn{2}{|l|}{ Dependent variables } \\
\hline$\overline{G O I N G \_C O N C E R N}$ & $\begin{array}{l}\text { Indicator variable equal to one if the company-year receives a } \\
\text { going concern audit opinion, zero otherwise. }\end{array}$ \\
\hline$M W$ & $\begin{array}{l}\text { Indicator variable equal to one if the company-year receives a } \\
\text { material weakness in the audit report on internal control over } \\
\text { financial reporting, zero otherwise. }\end{array}$ \\
\hline \multicolumn{2}{|l|}{ Company-level } \\
\hline$\overline{A C C E S S}$ & $\begin{array}{l}\text { Indicator variable equal to one if the company-year is subject } \\
\text { to PCAOB inspection access, zero otherwise. Information } \\
\text { obtained from the PCAOB website www.pcaobus.org. }\end{array}$ \\
\hline POST & $\begin{array}{l}\text { Indicator variable equal to one for company-years after } \\
\text { PCAOB regulation commences. POST equals one for all } \\
\text { audits of fiscal year } 2004 \text { reports and later. }\end{array}$ \\
\hline INSPECTED_FYEAR & $\begin{array}{l}\text { Indicator variable equal to one if the company-year's auditor } \\
\text { was inspected by the PCAOB. For example, if PCAOB } \\
\text { inspection fieldwork occurred during July } 17-J u l y ~ 24,2007, \text { I } \\
\text { code INSPECTED_FYEAR equal to one for for fiscal year } \\
2006 \text { reports of clients of the inspected auditor. }\end{array}$ \\
\hline$S I Z E$ & The natural log of total assets. \\
\hline$L O S S$ & $\begin{array}{l}\text { Indicator variable equal to one if the company-year reports a } \\
\text { loss, zero otherwise. }\end{array}$ \\
\hline$R O A$ & Income before extraordinary items, scaled by total assets. \\
\hline altZSCORE & $\begin{array}{l}\text { Altman }(1968) \text { bankruptcy risk score calculated as }(1.2 *(\text { net } \\
\text { current assets scaled by total assets })+1.4 *(\text { retained earnings } \\
\text { scaled by total assets })+3.3 *(\text { earnings before interest and taxes } \\
\text { scaled by total assets })+0.006 *(\text { market value of equity scaled } \\
\text { by long-term debt })+0.009 *(\text { total revenue scaled by total } \\
\text { assets }) .\end{array}$ \\
\hline CASH & Total cash and short-term investments scaled by total assets. \\
\hline$L E V$ & Leverage ratio, total liabilities scaled by total assets. \\
\hline
\end{tabular}




\section{APPENDIX A: VARIABLE DESCRIPTIONS}

\begin{tabular}{|c|c|}
\hline Variable & Description \\
\hline REPLAG & $\begin{array}{l}\text { The number of days from the fiscal year end date to the audit } \\
\text { report date. }\end{array}$ \\
\hline$A G E$ & $\begin{array}{l}\text { The natural log of the number of years a company has been } \\
\text { listed in the COMPUSTAT database. }\end{array}$ \\
\hline$M T B$ & Market to book ratio. \\
\hline$O P C F$ & Operating cash flows scaled by total assets. \\
\hline$L A G \_G C$ & $\begin{array}{l}\text { Indicator variable equal to one if the company received a going } \\
\text { concern opinion in the prior year. }\end{array}$ \\
\hline CROSS & $\begin{array}{l}\text { Indicator variable equal to one if the company is listed on an } \\
\text { stock exchange outside the United States in a given year. }\end{array}$ \\
\hline MAJOR & $\begin{array}{l}\text { Indicator variable equal to one if the company is listed on the } \\
\text { Bourse Frankfurt, Hong Kong, London or Tokyo stock } \\
\text { exchange. See As www.guides.lib.uchicago.edu. }\end{array}$ \\
\hline B4 & $\begin{array}{l}\text { Indicator variable equal to one if the auditor is an affiliate of a } \\
\text { Big } 4 \text { audit firm, zero otherwise. }\end{array}$ \\
\hline IFRS & $\begin{array}{l}\text { Indicator variable equal to one if the company-year financial } \\
\text { statements are reported on International Financial Reporting } \\
\text { Standards (IFRS) as issued by the IASB. }\end{array}$ \\
\hline HIGHLIT & $\begin{array}{l}\text { Indicator variable equal to one if the company operates in a } \\
\text { litigious industry. SIC codes include } 2832-37,3569-78,3599- \\
675,5199-62,7370-80 \text { (See Rogers and Stocken 2005; } \\
\text { Gramling et al. 2011). }\end{array}$ \\
\hline DIFF_LAW & $\begin{array}{l}\text { The difference between the rule of law measure (Kaufmann et } \\
\text { al 2010) measured at the auditor location and company } \\
\text { headquarters location. }\end{array}$ \\
\hline L_SEGMENTS & Natural log of the number of business and operating segments. \\
\hline D_RESTRUCTURE & $\begin{array}{l}\text { Indicator variable equal to one if the company reports } \\
\text { restructuring charges in a given year. }\end{array}$ \\
\hline
\end{tabular}




\section{APPENDIX A: VARIABLE DESCRIPTIONS}

\begin{tabular}{|c|c|}
\hline Variable & Description \\
\hline D_ACQUISITION & $\begin{array}{l}\text { Indicator variable equal to one if the company reports } \\
\text { acquisition charges in a given year. }\end{array}$ \\
\hline \multicolumn{2}{|l|}{ Country-level } \\
\hline$\overline{R U L E \_O F \_L A} W$ & $\begin{array}{l}\text { Rule of law measure from the Worldwide Governance } \\
\text { Indicators created by the World Bank (Kaufmann et al 2010). } \\
\text { Rule of law measures "the extent to which agents have } \\
\text { confidence in and abide by the rules of society, and in } \\
\text { particular the quality of contract enforcement, property rights, } \\
\text { the police, and the courts, as well as the likelihood of crime } \\
\text { and violence." }\end{array}$ \\
\hline GDP_CAPITA & $\begin{array}{l}\text { Gross domestic product scaled by population of the auditor } \\
\text { country. Obtained from the World Bank website } \\
\text { (http://data.worldbank.org/indicator). }\end{array}$ \\
\hline GDP_GROWTH & $\begin{array}{l}\text { The year over year change in GDP scaled by the previous year } \\
\text { GDP. Obtained from the World Bank website } \\
\text { (http://data.worldbank.org/indicator). }\end{array}$ \\
\hline$L \_G D P$ & $\begin{array}{l}\text { Natural log of GDP. Obtained from the World Bank website } \\
\text { (http://data.worldbank.org/indicator). }\end{array}$ \\
\hline$M K T \_S I Z E$ & $\begin{array}{l}\text { A country's total market capitalization (in \$US) in a year as a } \\
\text { percentage of gross domestic product. Obtained from the } \\
\text { World Bank website (http://data.worldbank.org/indicator). }\end{array}$ \\
\hline LIABILITY & $\begin{array}{l}\text { Measure of auditor liability at the auditor country-level as } \\
\text { defined by La Porta et al. (2006). This variable provides an } \\
\text { index of "the procedural difficulty in recovering losses from } \\
\text { the auditor in a civil liability case for losses due to misleading } \\
\text { statements in the audited financial information accompanying } \\
\text { the prospectus." }\end{array}$ \\
\hline
\end{tabular}




\section{APPENDIX B}

\section{TABLES}

Table 1 Sample selection and observations by year.................. 46

Table 2 Company-year observations by auditor location............... 47

Table 3 Descriptive statistics partitioned on inspection exposure........ 49

Table 4 Correlations of country-level variables..................... 50

Table 5 Logistic regression of PCAOB inspection access and going concern opinions in the post-PCAOB period............ 51

Table 6 Logistic regression of PCAOB inspection access and going concern opinions in the pre- and post-PCAOB period...... 52

Table 7 Logistic regression of PCAOB inspection access on auditor reported material weaknesses........................ 53

Table 8 Additional tests: PCAOB inspection access and going concern opinions................................... 54

Table 9 Additional tests: PCAOB inspection access and auditor reported material weaknesses.............................. 55 


\section{TABLE 1}

Sample selection and observations by year

Panel A:

Sample Selection

$\underline{\mathbf{N}}$

Company-year observations of foreign companies listed in the US in 2004 2010

Less:

Total assets missing, zero or less than $\$ 1$ million

Market value of equity missing or zero

Financial companies (SIC code 6000-6999)

Missing control variables

Foreign companies audited by U.S. auditors

Final sample for tests on 2004-2010 data - going concern model

4,670

add in 2001-2003 observations

Total observations (2001-2010) - for going concern changes test

1,562

6,232

Final sample for tests on 2004-2010 data - going concern model

Firms without SOX 404 opinion data

Final sample - material weakness test

1,905

Panel B:

Observations by year (2004-2010)

Going Concern Sample

$\begin{array}{ccccc}\underline{\text { Year }} & & \underline{\mathrm{N}} & \begin{array}{c}\text { Unique } \\ \text { auditors }\end{array} & \underline{\mathrm{GC}} \\ 2004 & 697 & 137 & 0.06 \\ 2005 & 720 & 143 & 0.06 \\ 2006 & 697 & 138 & 0.08 \\ 2007 & 670 & 141 & 0.09 \\ 2008 & 634 & 146 & 0.12 \\ 2009 & 628 & 144 & 0.10 \\ 2010 & 624 & 134 & 0.09\end{array}$

Total

\begin{tabular}{ll}
5 & 231 \\
\hline
\end{tabular}

\section{Material Weakness Sample}

\begin{tabular}{ccc}
$\underline{\mathrm{N}}$ & $\begin{array}{c}\text { Unique } \\
\text { auditors }\end{array}$ & $\underline{\mathrm{MW}}$ \\
26 & 11 & 0.31 \\
38 & 22 & 0.05 \\
257 & 81 & 0.06 \\
382 & 102 & 0.11 \\
410 & 111 & 0.07 \\
396 & 108 & 0.05 \\
396 & 102 & 0.05 \\
\cline { 1 - 1 } & \multicolumn{2}{l}{0.07} \\
\hline \hline
\end{tabular}

\section{Notes:}

Panel A details the sample selection procedures. Panel B details the observations by year. Going concern sample is the observations by year included in the going concern opinion tests. Material weakness sample is the observations by year used in the material weakness tests. $\mathrm{N}$ is the number of company-years in the year. Unique Auditors is the number of unique audit firms issuing an audit opinion in the given year. GC is the mean number of going concern opinions issued in the year. MW is the mean number of material weakness opinions issued in the year. 
TABLE 2

Company-year observations by auditor location

PCAOB Inspections Allowed

PCAOB Inspections Barred

\begin{tabular}{|c|c|c|c|c|c|c|c|c|c|c|c|c|c|}
\hline \multicolumn{7}{|c|}{ PCAUB InspecUOns AULWea } & \multicolumn{7}{|c|}{ 年 } \\
\hline Country & $\mathrm{N}$ & $\mathrm{GC}$ & $\begin{array}{c}\mathrm{N}- \\
\text { distress }\end{array}$ & $\begin{array}{c}\text { GC- } \\
\text { distress }\end{array}$ & $\begin{array}{l}\mathrm{N}- \\
\mathrm{MW}\end{array}$ & MW & Country & $\mathrm{N}$ & $\mathrm{GC}$ & $\begin{array}{c}\mathrm{N}- \\
\text { distress }\end{array}$ & $\begin{array}{c}\text { GC- } \\
\text { distress }\end{array}$ & $\begin{array}{c}\text { N- } \\
\text { MW }\end{array}$ & MW \\
\hline Argentina & 75 & 6 & 14 & 5 & 36 & 0 & Belgium & 11 & 0 & 0 & 0 & 6 & 0 \\
\hline Australia & 75 & 3 & 41 & 3 & 15 & 0 & China & 272 & 4 & 88 & 4 & 151 & 17 \\
\hline Austria & 7 & 0 & 2 & 0 & 1 & 0 & Cyprus & 1 & 0 & 0 & 0 & 0 & 0 \\
\hline Bermuda & 1 & 0 & 0 & 0 & 0 & 0 & Denmark & 16 & 0 & 2 & 0 & 11 & 0 \\
\hline Brazil & 111 & 2 & 12 & 0 & 74 & 5 & Finland & 13 & 0 & 0 & 0 & 7 & 0 \\
\hline Canada & 1,783 & 295 & 1,130 & 283 & 684 & 67 & France & 99 & 3 & 38 & 3 & 46 & 0 \\
\hline Colombia & 3 & 0 & 0 & 0 & 2 & 1 & Greece & 100 & 10 & 25 & 6 & 60 & 2 \\
\hline Hong Kong & 126 & 9 & 57 & 6 & 30 & 2 & Hong Kong & 251 & 10 & 83 & 10 & 111 & 15 \\
\hline India & 73 & 0 & 17 & & 42 & 6 & Hungary & 8 & 0 & 1 & 0 & 5 & 2 \\
\hline Indonesia & 14 & 0 & 0 & 0 & 10 & 2 & Ireland & 45 & 0 & 23 & 0 & 21 & 0 \\
\hline Israel & 480 & 23 & 271 & 22 & 122 & 4 & Italy & 36 & 1 & 12 & 1 & 17 & 1 \\
\hline Japan & 142 & 0 & 16 & & 78 & 0 & Luxembourg & 12 & 0 & 0 & 0 & 10 & 0 \\
\hline Kazakhstan & 1 & 0 & 0 & 0 & 0 & 0 & Netherlands & 61 & 0 & 15 & 0 & 29 & 0 \\
\hline Korea (South) & 51 & 2 & 15 & 2 & 28 & 1 & Norway & 31 & 0 & 1 & 0 & 17 & 0 \\
\hline New Zealand & 8 & 1 & 5 & 1 & 3 & 0 & Singapore & 13 & 0 & 4 & 0 & 4 & 1 \\
\hline Panama & 6 & 0 & 0 & 0 & 5 & 0 & Spain & 23 & 0 & 1 & 0 & 15 & 1 \\
\hline Peru & 7 & 0 & 0 & 0 & 5 & 0 & Sweden & 16 & 0 & 0 & 0 & 7 & 0 \\
\hline Philippines & 11 & 3 & 4 & 3 & 5 & 0 & Switzerland & 39 & 2 & 11 & 2 & 25 & 0 \\
\hline Russia & 34 & 1 & 1 & 0 & 22 & 11 & Turkey & 7 & 0 & 0 & 0 & 5 & 2 \\
\hline Singapore & 11 & 0 & 3 & 0 & 7 & 3 & U.K. & 28 & 0 & 6 & 0 & 27 & 0 \\
\hline South Africa & 54 & 1 & 22 & 1 & 29 & 2 & & & & & & & \\
\hline Thailand & 1 & 0 & 0 & 0 & 0 & 0 & & & & & & & \\
\hline U.K. & 227 & 5 & 52 & 5 & 108 & 2 & & & & & & & \\
\hline Venezuela & 3 & 0 & 0 & 0 & 1 & 0 & & & & & & & \\
\hline
\end{tabular}




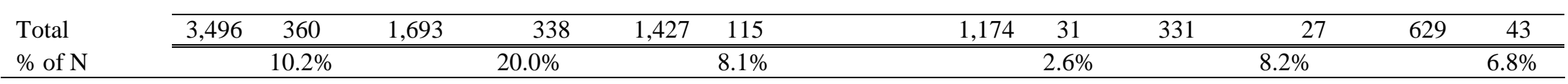

Notes:

Country is the location of the auditor for each company-year. $\mathrm{N}$ is the total company-years for each country in the going concern sample. GC is the number of going concern opinions issued in a given country. N-MW is the number of company-years included in the material weakness tests. MW is the number of internal control audit opinions with reported material weaknesses. Certain countries (United Kingdom, Singapore), appear in both columns as these countries either commenced barring PCAOB inspection or began allowing PCAOB inspections during the sample period. Hong Kong auditors also appears in both columns as Hong Kong-based audits of mainland Chinese companies are barred from PCAOB inspection, while Hong Kong based audits of non-mainland Chinese companies are granted inspection access. 
TABLE 3

Descriptive Statistics partitioned on inspection access

\begin{tabular}{|c|c|c|c|c|c|c|c|}
\hline \multirow[b]{3}{*}{ Company Level: } & \multicolumn{3}{|c|}{ PCAOB Inspections Allowed } & \multicolumn{3}{|c|}{ PCAOB Inspections Barred } & \multirow{2}{*}{$\begin{array}{c}\text { Diff in } \\
\text { means }\end{array}$} \\
\hline & $\mathrm{N}$ & Mean & Median & $\mathrm{N}$ & Mean & Median & \\
\hline & & & & & & & \\
\hline$\overline{\text { GOING_CONCERN }}$ & 3,496 & 0.103 & 0.000 & 1,174 & 0.026 & 0.000 & $<0.01$ \\
\hline$M W$ & 1280 & 0.070 & 0.000 & 625 & 0.067 & 0.000 & 0.801 \\
\hline SIZE & 3,496 & 6.008 & 5.862 & 1,174 & 7.326 & 6.840 & $<0.01$ \\
\hline LOSS & 3,496 & 0.440 & 0.000 & 1,174 & 0.228 & 0.000 & $<0.01$ \\
\hline$R O A$ & 3,496 & -0.102 & 0.016 & 1,174 & 0.029 & 0.051 & $<0.01$ \\
\hline CASH & 3,496 & 0.226 & 0.138 & 1,174 & 0.269 & 0.172 & $<0.01$ \\
\hline$L E V$ & 3,496 & 0.441 & 0.430 & 1,174 & 0.459 & 0.473 & 0.068 \\
\hline$M T B$ & 3,496 & 3.258 & 2.110 & 1,174 & 2.745 & 1.899 & $<0.01$ \\
\hline$O P C F$ & 3,496 & -0.006 & 0.055 & 1,174 & 0.081 & 0.092 & $<0.01$ \\
\hline altZSCORE & 3,496 & 0.702 & 0.599 & 1,174 & 0.688 & 0.622 & 0.43 \\
\hline D_RESTRUCTURE & 3,496 & 0.158 & 0.000 & 1,174 & 0.233 & 0.000 & $<0.01$ \\
\hline D_ACQUISITION & 3,496 & 0.026 & 0.000 & 1,174 & 0.032 & 0.000 & 0.29 \\
\hline L_SEGMENTS & 3,496 & 1.593 & 1.609 & 1,174 & 1.631 & 1.386 & 0.016 \\
\hline$R E P \_L A G$ & 3,496 & 95.447 & 83.000 & 1,174 & 110.420 & 101.000 & $<0.01$ \\
\hline$B 4$ & 3,496 & 0.820 & 1.000 & 1,174 & 0.880 & 1.000 & $<0.01$ \\
\hline$A G E$ & 3,496 & 2.398 & 2.398 & 1,174 & 2.025 & 2.079 & $<0.01$ \\
\hline CROSS & 3,496 & 0.377 & 0.000 & 1,174 & 0.496 & 0.000 & $<0.01$ \\
\hline MAJOR & 3,496 & 0.112 & 0.000 & 1,174 & 0.154 & 0.000 & $<0.01$ \\
\hline IFRS & 3,496 & 0.092 & 0.000 & 1,174 & 0.284 & 0.000 & $<0.01$ \\
\hline$D I F F_{-} L A W$ & 3,496 & 0.001 & 0.000 & 1,174 & 0.081 & 0.000 & $<0.01$ \\
\hline \multicolumn{8}{|l|}{ Country-Level } \\
\hline GDP_CAPITA & 3,496 & 30841.941 & 35087.893 & 1,178 & 29386.000 & 30864.880 & $<0.01$ \\
\hline GDP_GROWTH & 3,496 & 0.076 & 0.104 & 1,178 & 0.066 & 0.074 & $<0.01$ \\
\hline$L \_G D P$ & 3,496 & 27.449 & 27.757 & 1,178 & 27.450 & 27.182 & 0.98 \\
\hline$M K T \_S I Z E$ & 3,496 & 1.283 & 1.257 & 1,178 & 2.336 & 0.869 & $<0.01$ \\
\hline RULE_OF_LAW & 3,496 & 0.752 & 0.833 & 1,178 & 0.706 & 0.800 & $<0.01$ \\
\hline LIABILITY & 3,496 & 0.790 & 1.000 & 1,178 & 0.561 & 0.660 & $<0.01$ \\
\hline
\end{tabular}

Notes:

Column 1 includes company-years where auditors are subject to PCAOB inspection exposure (ACCESS = 1). Column 2 includes company-years where auditors are not subject to PCAOB inspection exposure $($ ACCESS $=0)$. See Appendix for variable definitions. 
TABLE 4

Correlations of country-level variables

\begin{tabular}{|c|c|c|c|c|c|c|c|c|}
\hline \multicolumn{9}{|c|}{ Panel A: Going concern sample correlations $(n=4,670)$} \\
\hline & Variable & 1. & 2. & 3. & 4. & 5. & 6. & 7. \\
\hline 1. & ACCESS & & 0.12 & 0.00 & 0.05 & 0.04 & -0.23 & 0.38 \\
\hline 2. & $R U L E \_O F \_L A W$ & 0.17 & & $\mathbf{0 . 0 3}$ & -0.24 & 0.85 & 0.20 & 0.57 \\
\hline 3. & $L \_G D P$ & -0.05 & 0.19 & & 0.07 & 0.12 & -0.32 & 0.17 \\
\hline 4. & GDP_GROWTH & 0.06 & -0.18 & 0.09 & & -0.24 & -0.10 & -0.03 \\
\hline 5. & GDP_CAPITA & 0.10 & 0.87 & 0.34 & -0.21 & & 0.05 & 0.48 \\
\hline 6. & $M K T \_S I Z E$ & 0.10 & 0.36 & -0.07 & -0.03 & 0.25 & & 0.03 \\
\hline 7. & LIABILITY & 0.39 & 0.72 & 0.17 & 0.01 & 0.56 & 0.39 & \\
\hline
\end{tabular}

Panel B: Distressed Going concern sample country-level correlations $(\mathbf{n}=\mathbf{2 , 0 2 5})$

\begin{tabular}{|c|c|c|c|c|c|c|c|c|}
\hline & Variable & 1. & 2. & 3. & 4. & 5. & 6. & 7. \\
\hline 1. & ACCESS & & 0.28 & -0.04 & 0.02 & 0.20 & -0.26 & 0.52 \\
\hline 2. & $R U L E \_O F \_L A W$ & 0.32 & & 0.14 & -0.16 & 0.89 & 0.13 & 0.61 \\
\hline 3. & $L \_G D P$ & -0.10 & 0.39 & & 0.10 & 0.25 & -0.32 & 0.30 \\
\hline 4. & GDP_GROWTH & 0.05 & -0.17 & 0.11 & & -0.17 & -0.08 & 0.03 \\
\hline 5. & GDP_CAPITA & 0.18 & 0.87 & 0.53 & -0.12 & & -0.02 & 0.53 \\
\hline 6. & MKT_SIZE & 0.09 & 0.22 & -0.02 & 0.05 & 0.17 & & -0.07 \\
\hline 7. & LIABILITY & 0.49 & 0.75 & 0.29 & 0.09 & 0.61 & 0.26 & \\
\hline
\end{tabular}

Panel C: Material weakness sample country level correlations $(n=1,905)$

\begin{tabular}{llccccccc}
\hline \multicolumn{2}{l}{ Variable } & 1. & 2. & 3. & 4. & 5. & 6. & 7. \\
\hline 1. & ACCESS & & $\mathbf{0 . 0 4}$ & 0.02 & $\mathbf{0 . 0 5}$ & -0.02 & $\mathbf{- 0 . 2 2}$ & $\mathbf{0 . 3 0}$ \\
2. & RULE_OF_LAW & $\mathbf{0 . 1 0}$ & & $\mathbf{- 0 . 0 5}$ & $\mathbf{- 0 . 2 7}$ & 0.86 & $\mathbf{0 . 2 1}$ & $\mathbf{0 . 5 4}$ \\
3. & L_GDP & $\mathbf{- 0 . 0 5}$ & 0.03 & & $\mathbf{0 . 0 9}$ & -0.02 & $\mathbf{- 0 . 3 6}$ & $\mathbf{0 . 0 9}$ \\
4. & GDP_GROWTH & $\mathbf{0 . 0 7}$ & $\mathbf{- 0 . 2 8}$ & 0.12 & & $\mathbf{- 0 . 2 2}$ & $\mathbf{- 0 . 0 5}$ & $\mathbf{- 0 . 0 4}$ \\
5. & GDP_CAPITA & $\mathbf{0 . 0 6}$ & $\mathbf{0 . 8 7}$ & $\mathbf{0 . 1 3}$ & $\mathbf{- 0 . 2 2}$ & & $\mathbf{0 . 0 5}$ & $\mathbf{0 . 4 4}$ \\
6. & MKT_SIZE & $\mathbf{0 . 0 6}$ & $\mathbf{0 . 3 7}$ & $\mathbf{- 0 . 1 3}$ & 0.02 & $\mathbf{0 . 2 1}$ & & $\mathbf{0 . 0 8}$ \\
7. & LIABILITY & $\mathbf{0 . 3 2}$ & $\mathbf{0 . 7 1}$ & $\mathbf{0 . 0 8}$ & $\mathbf{- 0 . 0 5}$ & $\mathbf{0 . 5 3}$ & $\mathbf{0 . 4 2}$ & \\
\hline
\end{tabular}

Notes:

Correlation coefficients in bold are statistically significant at the $10 \%$ level, two-tailed. Pearson correlations are presented across the top, while Spearman correlations are across the bottom. See Appendix for variable definitions. 
TABLE 5

\section{Logistic regression of PCAOB inspection access and going concern opinions in the post-PCAOB period}

\begin{tabular}{|c|c|c|c|c|}
\hline \multirow[b]{2}{*}{$\underline{\text { Variable }}$} & \multicolumn{2}{|c|}{ (1) All } & \multicolumn{2}{|c|}{ (2) Distressed only } \\
\hline & $\underline{\text { Coeff }}$ & $p$-value & $\underline{\text { Coeff }}$ & $p$-value \\
\hline Intercept & -17.669 & $<0.01$ & -13.779 & 0.03 \\
\hline ACCESS & 0.823 & $<0.01$ & 0.574 & 0.07 \\
\hline SIZE & -0.232 & $<0.01$ & -0.153 & $<0.01$ \\
\hline LOSS & 1.371 & $<0.01$ & & \\
\hline$R O A$ & -0.548 & 0.01 & -0.766 & $<0.01$ \\
\hline altZSCORE & -0.366 & $<0.01$ & -0.261 & 0.03 \\
\hline CASH & -1.571 & $<0.01$ & -1.535 & $<0.01$ \\
\hline$L E V$ & 0.821 & $<0.01$ & 0.646 & $<0.01$ \\
\hline$R E P \_L A G$ & 0.007 & $<0.01$ & 0.006 & $<0.01$ \\
\hline$A G E$ & -0.159 & 0.15 & -0.228 & 0.04 \\
\hline$M T B$ & 0.005 & 0.62 & 0.002 & 0.84 \\
\hline$O P C F$ & 0.001 & 0.98 & & \\
\hline $\operatorname{lag}_{-} G C$ & 2.410 & $<0.01$ & 2.289 & $<0.01$ \\
\hline CROSS & -0.766 & 0.01 & -0.543 & 0.11 \\
\hline MAJOR & -0.505 & 0.37 & -0.197 & 0.72 \\
\hline B4 & -0.489 & 0.02 & -0.435 & 0.03 \\
\hline IFRS & 0.092 & 0.86 & 0.117 & 0.81 \\
\hline HIGHLIT & 0.086 & 0.78 & 0.149 & 0.64 \\
\hline$D I F F_{-} L A W$ & 1.27 & 0.26 & 0.276 & 0.79 \\
\hline \multicolumn{5}{|l|}{ Country-level } \\
\hline$R U L E \_O F \_L A W$ & -4.29 & 0.07 & -3.526 & 0.17 \\
\hline$L \_G D P \_C A P I T A$ & 0.874 & 0.04 & 0.686 & 0.12 \\
\hline GDP_GROWTH & 0.088 & 0.95 & -0.596 & 0.73 \\
\hline$L \_G D P$ & 0.323 & 0.01 & 0.266 & 0.07 \\
\hline$M K T \_S I Z E$ & -0.027 & 0.67 & -0.011 & 0.88 \\
\hline LIABILITY & -0.107 & 0.89 & -0.525 & 0.53 \\
\hline $\mathrm{N}$ & 4,670 & & 2,025 & \\
\hline Wald Chi-square & 701.11 & & 398.19 & \\
\hline Pseudo R-square & 0.46 & & 0.33 & \\
\hline
\end{tabular}

Notes: Standard errors are clustered at the company-level and year fixed effects are included in all models. Two-tailed $p$-values are reported. Column 1 includes all observations. Column 2 includes distressed company-years, those reporting a net loss or negative cash flows from operations. See Appendix for variable definitions. 


\section{TABLE 6}

Logistic regression of $\mathrm{PCAOB}$ inspection access on going concern opinions in the pre- and post-PCAOB period

\begin{tabular}{|c|c|c|c|c|c|c|}
\hline \multirow[b]{2}{*}{ Variable } & \multicolumn{2}{|c|}{ (1)Pre-PCAOB } & \multicolumn{2}{|c|}{ (2) Pooled } & \multicolumn{2}{|c|}{ (3) Pooled distressed } \\
\hline & $\underline{\text { Coeff. }}$ & $p$-value & $\underline{\text { Coeff. }}$ & $p$-value & $\underline{\text { Coeff. }}$ & $p$-value \\
\hline Intercept & -12.478 & 0.03 & -14.840 & $<0.01$ & -14.004 & $<0.01$ \\
\hline POST*ACCESS & & & 1.458 & $<0.01$ & 1.520 & $<0.01$ \\
\hline ACCESS & -0.793 & 0.16 & -0.556 & 0.19 & -0.719 & 0.08 \\
\hline POST & & & -1.414 & 0.01 & -1.102 & 0.06 \\
\hline SIZE & -0.163 & 0.06 & -0.203 & $<0.01$ & -0.176 & $<0.01$ \\
\hline LOSS & 1.881 & $<0.01$ & 1.558 & $<0.01$ & & \\
\hline$R O A$ & 0.037 & 0.92 & -0.342 & 0.06 & -0.716 & $<0.01$ \\
\hline altZSCORE & -0.376 & 0.08 & -0.334 & $<0.01$ & -0.257 & 0.01 \\
\hline CASH & -1.362 & 0.06 & -1.514 & $<0.01$ & -1.4778 & $<0.01$ \\
\hline$L E V$ & 2.258 & $<0.01$ & 1.083 & $<0.01$ & 0.877 & $<0.01$ \\
\hline$R E P \_L A G$ & 0.001 & 0.62 & 0.005 & $<0.01$ & 0.005 & $<0.01$ \\
\hline$A G E$ & -0.032 & 0.88 & -0.179 & 0.06 & -0.234 & 0.02 \\
\hline MTB & 0.004 & 0.83 & 0.006 & 0.46 & 0.006 & 0.54 \\
\hline$O P C F$ & -2.398 & $<0.01$ & -0.548 & 0.07 & & \\
\hline lag_GC & 1.614 & $<0.01$ & 2.195 & $<0.01$ & 2.097 & $<0.01$ \\
\hline CROSS & -0.712 & 0.12 & -0.712 & $<0.01$ & -0.609 & 0.03 \\
\hline MAJOR & -0.323 & 0.65 & -0.652 & 0.15 & -0.609 & 0.23 \\
\hline$B 4$ & -0.77 & 0.02 & -0.366 & $<0.01$ & -0.460 & $<0.01$ \\
\hline IFRS & & & 0.014 & 0.97 & 0.084 & 0.85 \\
\hline HIGHLIT & -0.601 & 0.35 & -0.238 & 0.39 & -0.220 & 0.44 \\
\hline$D I F F_{-} L A W$ & 3.125 & 0.27 & 1.478 & 0.12 & 0.774 & 0.46 \\
\hline \multicolumn{7}{|l|}{ Country-level } \\
\hline$R U L E \_O F \_L A W$ & -8.867 & $<0.01$ & -5.281 & $<0.01$ & -4.852 & 0.03 \\
\hline GDP_CAPITA & 0.607 & 0.21 & 0.751 & $<0.01$ & 0.700 & 0.07 \\
\hline GDP_GROWTH & -1.844 & $<0.01$ & -2.458 & $<0.01$ & -2.989 & $<0.01$ \\
\hline$L \_G D P$ & 0.363 & 0.03 & 0.331 & $<0.01$ & 0.364 & $<0.01$ \\
\hline$M K T \_S I Z E$ & 0.030 & 0.93 & -0.003 & 0.96 & 0.010 & 0.88 \\
\hline LIABILITY & 0.855 & 0.77 & 0.112 & 0.85 & 0.299 & 0.68 \\
\hline $\mathrm{N}$ & 1560 & & 6,232 & & 2,792 & \\
\hline Wald chi-square & 352.04 & & 1538.44 & & 510.91 & \\
\hline Pseudo R-square & 0.44 & & 0.44 & & 0.32 & \\
\hline
\end{tabular}

Notes: Standard errors are clustered at the company-level and year fixed effects are included in all models. Two-tailed $p$-values are reported. Column 1 includes all pre-PCAOB regulatory period observations, Column 2 includes pre- and post PCAOB regulatory period observations, and Column 3 includes only distressed company-years, those reporting a net loss or negative cash flows from operations for the pooled sample in Column 2. See Appendix for variable definitions. 
TABLE 7

Logistic regression of $\mathrm{PCAOB}$ inspection access on auditor reported material weaknesses

\begin{tabular}{lcc}
\hline Variable & $\underline{\text { Coeff }}$ & p-value \\
Intercept & 0.97 & 0.87 \\
ACCESS & 0.800 & 0.03 \\
SIZE & 0.014 & 0.87 \\
LOSS & 1.137 & $<0.01$ \\
altZSCORE & 0.374 & 0.12 \\
L_SEGMENTS & -0.081 & 0.78 \\
AGE & -0.406 & 0.07 \\
S_GROWTH & -0.197 & 0.35 \\
D_RESTRUCTURE & 0.157 & 0.64 \\
D_ACQUISITION & -0.141 & 0.84 \\
CROSS & -1.046 & 0.02 \\
MAJOR & -0.826 & 0.15 \\
B4 & -1.340 & $<0.01$ \\
IFRS & 0.108 & 0.81 \\
HIGHLIT & -0.055 & 0.88 \\
DIFF_LAW & 3.570 & 0.02 \\
Country-level & & \\
RULE_OF_LAW & & \\
GDP_CAPITA & -2.340 & 0.23 \\
GDP_GROWTH & -0.188 & 0.52 \\
L_GDP & -0.597 & 0.69 \\
MKT_SIZE & 0.051 & 0.79 \\
LIABILITY & 0.032 & 0.68 \\
N & -0.930 & 0.34 \\
Wald Chi-square & & \\
R-square & 161.31 & \\
& 0.18 & \\
\hline
\end{tabular}

Notes:

Two-tailed $p$-values are reported. Standard errors are clustered at the company level and year fixed effects are included in the model. See Appendix for variable definitions. 
TABLE 8

Additional tests: PCAOB inspection access and going concern opinions

\begin{tabular}{|c|c|c|c|c|}
\hline \multirow[b]{2}{*}{ Variable } & \multicolumn{2}{|c|}{ (1) All } & \multicolumn{2}{|c|}{ (2) No inspect countries } \\
\hline & $\underline{\text { Coeff }}$ & $\mathrm{p}$-value & $\underline{\text { Coeff }}$ & p-value \\
\hline Intercept & -17.483 & $<0.01$ & -20.640 & 0.16 \\
\hline ACCESS & 0.807 & $<0.01$ & 3.979 & $<0.01$ \\
\hline INSPECTED_FYEAR & 0.248 & 0.21 & & \\
\hline SIZE & -0.232 & $<0.01$ & 0.090 & 0.76 \\
\hline LOSS & 1.380 & $<0.01$ & -0.26 & 0.76 \\
\hline$R O A$ & -0.545 & 0.02 & -2.938 & 0.03 \\
\hline altZSCORE & -0.371 & $<0.01$ & -3.167 & $<0.01$ \\
\hline $\mathrm{CASH}$ & -1.554 & $<0.01$ & -9.841 & $<0.01$ \\
\hline$L E V$ & 0.832 & $<0.01$ & 3.736 & 0.02 \\
\hline$R E P \_L A G$ & 0.007 & $<0.01$ & 0.025 & $<0.01$ \\
\hline$A G E$ & -0.164 & 0.14 & 0.495 & 0.45 \\
\hline$M T B$ & 0.005 & 0.65 & -0.041 & 0.35 \\
\hline$O P C F$ & 0.017 & 0.96 & -7.550 & $<0.01$ \\
\hline lag_GC & 2.407 & $<0.01$ & 3.128 & $<0.01$ \\
\hline CROSS & -0.762 & 0.01 & 0.033 & 0.96 \\
\hline MAJOR & -0.473 & 0.40 & -3.432 & $<0.01$ \\
\hline$B 4$ & -0.484 & 0.02 & -3.983 & $<0.01$ \\
\hline IFRS & 0.079 & 0.88 & -3.770 & $<0.01$ \\
\hline HIGHLIT & 0.096 & 0.75 & 0.224 & 0.86 \\
\hline$D I F F_{-} L A W$ & 1.280 & 0.26 & 2.493 & 0.34 \\
\hline \multicolumn{5}{|l|}{ Country-level } \\
\hline$R U L E \_O F \_L A W$ & -4.116 & 0.07 & 4.925 & 0.04 \\
\hline L_GDP_CAPITA & 0.852 & 0.04 & & \\
\hline GDP_GROWTH & 0.082 & 0.95 & 10.597 & 0.18 \\
\hline$L \_G D P$ & 0.322 & 0.01 & 0.565 & 0.30 \\
\hline$M K T \_S I Z E$ & -0.030 & 0.66 & -0.184 & 0.30 \\
\hline LIABILITY & -0.150 & 0.85 & -4.943 & 0.01 \\
\hline $\mathrm{N}$ & 4,670 & & 1,029 & \\
\hline Wald Chi-square & 702.35 & & 230.50 & \\
\hline R-square & 0.46 & & 0.37 & \\
\hline
\end{tabular}

(1) All

Notes:Two-tailed $p$-values are reported. Standard errors are clustered at the company level and year fixed effects are included in all models. Column (1) includes all observations. Column (2) includes companyyears headquartered in countries barring PCAOB inspection access. Due to multicollinearity between $R U L E \_O F_{-} L A W$ and $L_{-} G D P_{-} C A P I T A$ in this smaller subset of company-years $(\mathrm{n}=1,029)$ I drop $L_{-} G D P P_{-} C A P I T A$. Results are unchanged if I drop $R U L E_{-} O F_{-} L A W$ and retain $L_{-} G D P \_C A P I T A$. 
TABLE 9

Additional tests: PCAOB inspection access and auditor reported material weaknesses

\begin{tabular}{|c|c|c|c|c|}
\hline \multirow[b]{2}{*}{ Variable } & \multicolumn{2}{|c|}{ (1) All } & \multicolumn{2}{|c|}{ (2) No inspect countries } \\
\hline & $\underline{\text { Coeff }}$ & p-value & $\underline{\text { Coeff }}$ & p-value \\
\hline Intercept & 0.623 & 0.92 & 32.020 & 0.72 \\
\hline ACCESS & 0.773 & 0.03 & 2.207 & 0.06 \\
\hline INSPECTED_FYEAR & 0.251 & 0.35 & & \\
\hline SIZE & 0.013 & 0.87 & -0.005 & 0.98 \\
\hline LOSS & 1.149 & $<0.01$ & 0.64 & 0.16 \\
\hline altZSCORE & 0.378 & 0.12 & -0.506 & 0.41 \\
\hline L_SEGMENTS & -0.079 & 0.78 & 1.098 & 0.01 \\
\hline$A G E$ & -0.402 & 0.08 & -0.195 & 0.70 \\
\hline S_GROWTH & -0.192 & 0.36 & -0.379 & 0.32 \\
\hline D_RESTRUCTURE & 0.156 & 0.64 & 0.534 & 0.42 \\
\hline D_ACQUISITION & -0.172 & 0.81 & 0.809 & 0.35 \\
\hline CROSS & -1.052 & 0.02 & -1.327 & 0.26 \\
\hline MAJOR & -0.81 & 0.15 & -0.648 & 0.51 \\
\hline$B 4$ & -1.308 & $<0.01$ & -1.226 & 0.07 \\
\hline IFRS & 0.115 & 0.79 & -0.285 & 0.77 \\
\hline HIGHLIT & -0.054 & 0.88 & 0.648 & 0.26 \\
\hline$D I F F_{-} L A W$ & 3.612 & 0.02 & 8.568 & $<0.01$ \\
\hline \multicolumn{5}{|l|}{ Country-level } \\
\hline$R U L E \_O F \_L A W$ & -2.291 & 0.24 & 3.859 & 0.50 \\
\hline GDP_CAPITA & -0.192 & 0.51 & -1.827 & 0.04 \\
\hline GDP_GROWTH & -0.691 & 0.65 & 4.851 & 0.38 \\
\hline$L \_G D P$ & 0.063 & 0.74 & -0.646 & 0.03 \\
\hline$M K T \_S I Z E$ & 0.032 & 0.68 & -0.186 & 0.10 \\
\hline LIABILITY & -0.922 & 0.34 & -4.013 & 0.04 \\
\hline $\mathrm{N}$ & 1,905 & & 616 & \\
\hline Wald Chi-square & 162.00 & & 75.68 & \\
\hline Pseudo R-square & 0.18 & & 0.25 & \\
\hline
\end{tabular}

Notes:

Two-tailed $p$-values are reported. Standard errors are clustered at the company level and year fixed effects are included in all models. Column (1) includes all company-years in the material weakness sample. Column (2) includes only company-years for companies headquartered in countries barring PCAOB inspection access. In Column (2) ACCESS takes the value of one when the auditor is based in a country that allows PCAOB inspections. 


\section{APPENDIX C}

FIGURE

\section{Distribution of z-statistics for Interaction Effects in Table 6}

Panel A: Table 6 Column 1

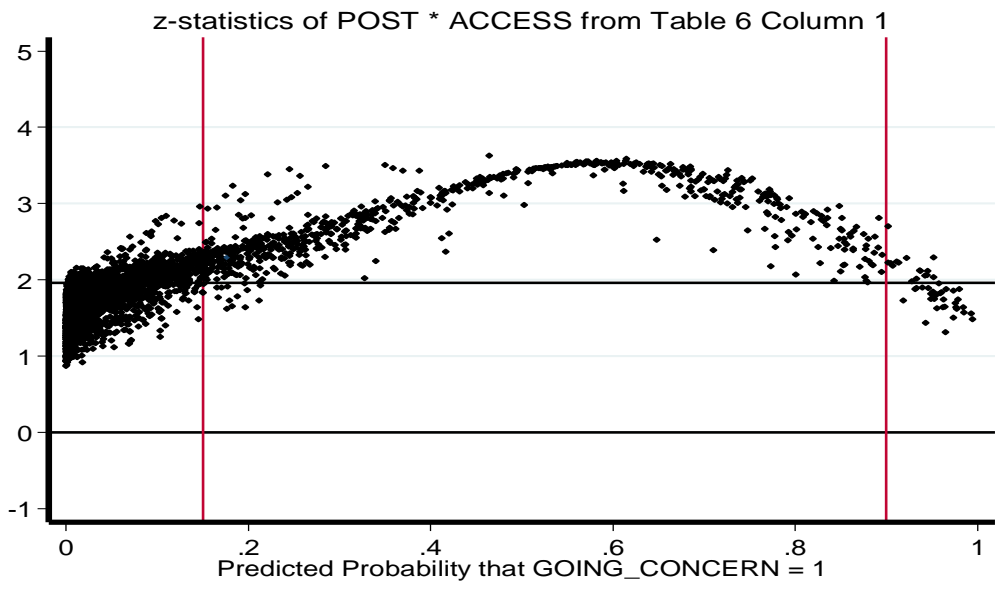

Panel B: Table 6 Column 2

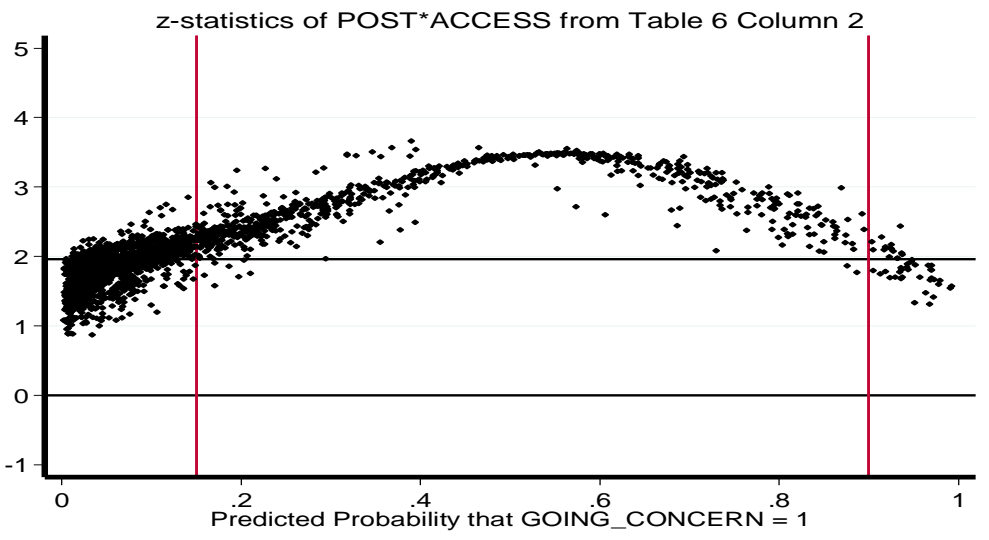

Figure 1 A provides the distribution of z-statistics for interaction effects of POST and ACCESS in the logistic model reported in Table 6 Column 1. Figure $1 \mathrm{~B}$ provides distribution of z-statistics for interaction effects of POST and ACCESS in the logistic model reported in Table 6 Column 2. 


\section{REFERENCES:}

Ai, C.,Norton, E.C., 2003. Interaction terms in logit and probit models. Economic Letters 80, 123-129.

Ashbaugh-Skaife, H., Collins, D.W., Kinney Jr., W.R., Lafond, R., 2009. The Effect of SOX Internal Control Deficiencies on Firm Risk and Cost of Equity. Journal of Accounting Research 47, 1-43.

Carcello, J.V., Neal, T., 2000. Audit Committee Composition and Auditor Reporting. The Accounting Review 75, 453-467.

Carcello, J.V., Neal, T., 2003. Audit committee characteristics and auditor dismissals following "new" going concern reports. The Accounting Review 78, 95-117.

Carcello, J.V., Carver, B.T., Neal, T.L., 2011a. Market Reaction to the PCAOB's Inability to Conduct Foreign Inspections. Working paper, University of Tennessee.

Carcello, J.V., Hollingsworth, C., Mastrolia, S.A., 2011b. The effect of PCAOB inspections on Big 4 audit quality. Research in Accounting Regulation 23, 85-96.

Carey, P., Simnett, R., 2006. Audit Partner Tenure and Audit Quality. The Accounting Review 81, 653-676.

DeFond, M.L., 2010. How should the auditors be audited? Comparing the PCAOB Inspections with the AICPA Peer Reviews. Journal of Accounting and Economics 49, 104-108.

DeFond, M.L., Lennox, C.S., 2011. The Effect of SOX on Small Auditor Exists and Audit Quality. Journal of Accounting and Economics 52, 21-40.

DeFond, M., Raghunandan, K., Subramanyam, K.R., 2002. Do Non-audit Service Fees Impair Auditor Independence? Evidence from Going Concern Audit Opinions. Journal of Accounting Research 40, 1247-1274.

Dhaliwal, D., Lamoreaux, P. T., Lennox, C.S., Mauler, L. M., 2013. Management Influence on Auditor Selection and Subsequent Impairments to Auditor Independence during the post-SOX period. Working paper, University of Arizona.

Doty, J.R., 2011. Keynote Address: The Global Dimension Conference on Audit Policy. Brussels, Belgium. June 30, 2011.

Doyle, J, Ge, W., McVay, S., 2007. Determinants of weaknesses in internal control over financial reporting. Journal of Accounting and Economics 44, 193-223. 
Glover, S.M., Prawitt, D.F., Taylor, M.H., 2009. Audit Standard Setting and Inspection for US Public Companies: A Critical Assessment and Recommendations for Fundamental Change. Accounting Horizons 23, 221-237.

Goh, B.G., Krishnan, J., Li, D., 2012. Auditor Reporting Under Section 404: The Association Between the Internal Control and Going Concern Audit Opinions. Contemporary Accounting Research (forthcoming).

Gordon, E.A., Greiner, A.J., Kohlbeck, M.J., Lin, S.W.J., Ashbaugh-Skaife, H., 2012. Challenges and Opportunities in Cross-Country Accounting Research. Accounting Horizons 27, 141-154.

Gramling, A.A., Krishnan, J., Zhang, Y., Are PCAOB-Identified Audit Deficiencies Associated with a Change in Reporting Decisions of Triennially Inspected audit firms? Auditing: A Journal of Practice and Theory 30, 59-79.

Gunny, K. and T. Zhang. 2009. PCAOB Inspection Reports and Audit Quality. Working paper, University of Colorado.

Hanson, J., 2012. Reflections on the State of the Audit Profession. Speech at the American Accounting Association, Auditing Section Mid-Year Meeting, Savannah, GA, January 23, 2012.

Hilary, G., Lennox, C.S., 2005. The credibility of self-regulation: Evidence from the accounting profession's peer review program. Journal of Accounting and Economics 40, 211-229.

Holthausen, R., 2009. Accounting Standards, Financial Reporting Outcomes, and Enforcement. Journal of Accounting Research 47, 447-58.

Houston, R.W., Stefaniak, C.M., 2013. Audit Partner Perceptions of Post-Audit Review Mechanisms: an Examination of Internal Quality Reviews and PCAOB Inspections. Accounting Horizons 27, 23-49.

Kaufmann, D., Kraay, A., Mastruzzi, M., 2010. The Worldwide Governance Indicators. The World Bank Development Research Group. September, 2010.

Kennedy, P., 2008. A Guide to Econometrics. Sixth edition. Edited by MIT Press, Cambridge, MA.

Kida, T., An Investigation into Auditor's Continuity and Related Qualification Judgments. Journal of Accounting Research. 18, 506-23. 
Kinney, W., 2005. Twenty-five years of audit deregulation and re-regulation: What does it mean for 2005 and beyond? Auditing: A Journal of Practice \& Theory 24 (Supplement), 89-109.

La Porta, R., Lopez-De-Silanes, F., Shleifer, A., Vishny, R., 1999. The Quality of Government. Journal of Law, Economics, and Organization 15, 222-79.

La Porta, R., Lopez-De-Silanes, F., Shleifer, A., 2006. What Works in Securities Laws? The Journal of Finance 61, 1-32.

Leuz, C., Nanda, D., Wysocki, P.D., 2003. Earnings management and investor protection: an international comparison. Journal of Financial Economics 69, 505-27.

Lennox, C., Pittman, J., 2010. Auditing the auditors: Evidence on the recent reforms to the external monitoring of audit firms. Journal of Accounting and Economics 49, 84103.

Michas, P., 2011. The Importance of Audit Profession Development in Emerging Market Countries. The Accounting Review 86, 1731-1764.

Norton, E.C., Wang, H., Ai, C., 2004. Computing interaction effects and standard errors in logit and probit models. The Stata Journal 3, 154-167.

Offermanns, M. Peek, E., 2011. Investor Reactions to PCAOB Inspection Reports. Working paper, Maastricht University.

Pagano, M., Immordino, G., 2007. Optimal Regulation of Auditing. CESifo Economic Studies 53, 363-388.

Public Company Accounting Oversight Board (PCAOB), 2003a. Rule 4004: Procedures Regarding Possible Violations. PCAOB, Washington, DC.

Public Company Accounting Oversight Board (PCAOB), 2003b. Registration System for Public Accounting Firms. PCAOB Release No. 2003-007., May 6, 2003.

Public Company Accounting Oversight Board (PCAOB), 2003c. Rules on Investigations and Adjudications. PCAOB Release No. 2003-015., September 23, 2003.

Public Company Accounting Oversight Board (PCAOB), 2004a. Registration deadline for non-US accounting firms. PCAOB Release No. 2004-003., PCAOB, March 11, 2004. 
Public Company Accounting Oversight Board (PCAOB), 2004b. Statement Concerning the Issuance of Inspection Reports. PCAOB Release No. 104-2004-001., PCAOB, August 26, 2004.

Public Company Accounting Oversight Board (PCAOB), 2004c. Auditing Standard No. 3: Audit Documentation.

Public Company Accounting Oversight Board (PCAOB), 2010. Staff Audit Practice Alert No. 6: Auditor considerations regarding using the work of other auditors and engaging assistants from outside the firm. PCAOB, July 12, 2010.

Public Company Accounting Oversight Board (PCAOB), 2011. Staff Audit Practice Alert No. 8: Audit risks in certain emerging markets. PCAOB October 3, 2011.

Reynolds, J.K., Francis, J.R., 2000. Does size matter? The influence of large clients on office-level auditor reporting decisions. Journal of Accounting and Economics 30, 375-400.

Rice, S. C., Weber, D., 2012. How Effective Is Internal Control Reporting under SOX 404? Determinants of the (Non-) Disclosure of Existing Material Weaknesses. Journal of Accounting Research 50, 811-43.

Rogers, J.L., Stocken, P.C., 2005. Credibility of management forecasts. The Accounting Review 80, 1233-60.

Securities and Exchange Commission (SEC). 2007. Acceptance from Foreign Private Issuers of Financial Statements Prepared in Accordance with International Financial Reporting Standards without Reconciliation to USGAAP. SEC Release Nos. 338879; 34-57026 Washington, D.C. December 21, 2007.

Srinivasan, S, A., Wahid, S., Yu, G., 2012. Admitting mistakes: An analysis of restatements by foreign firms listed in the US. Working paper, Harvard University. 